\title{
A tale of too many tasks: Fragmentation of tasks in motor learning and a call for model task paradigms
}

\author{
Rajiv Ranganathan *, Aimee D. Tomlinson, Rakshith Lokesh, Tzu-Hsiang Lin, and Priya Patel \\ Department of Kinesiology, Michigan State University
}

September 14, 2019

\begin{abstract}
Motor learning encompasses a broad set of phenomena that requires a diverse set of experimental paradigms. However, excessive variation in tasks across studies creates fragmentation that can adversely affect the collective advancement of knowledge. Here, we show that motor learning studies tend toward extreme fragmentation in the choice of tasks, with almost no overlap between tasks across studies. We argue that this extreme level of task fragmentation poses serious theoretical and methodological barriers to advancing the field. To address these barriers, we propose the need for developing common 'model' task paradigms which could be widely used across labs. Combined with the open sharing of methods and data, we suggest that these model task paradigms could be an important step in increasing the robustness of the motor learning literature and facilitating the cumulative process of science.
\end{abstract}

Keywords: replication, power, design, standardization, sample size, science

\section{Introduction}

In the context of theories in psychology, Mischel referred to the presence of a 'toothbrush problem' i.e., that "no self-respecting person wants to use anyone else's" [1]. In this paper, we show that experimental paradigms in motor learning suffer from a similar toothbrush problem; tasks used are extremely fragmented, with little to no overlap between different studies. We argue that this extreme fragmentation has negative consequences for the field from both theoretical and methodological perspectives. Finally, we propose the use of common 'model task paradigms' to address these issues.

\section{How Fragmented is Motor Learning?}

\subsection{Review of motor learning studies}

To quantify the degree of fragmentation in the motor learning literature, we selected publications in 2017 and 2018 from the following journals: Experimental Brain Research, Human Movement Science, Journal of Motor Behavior, Journal of Motor Learning and Development and Journal of Neurophysiology. These journals were selected as being representative of journals that publish motor learning

*Corresponding Author: Rajiv Ranganathan (rrangana@msu.edu) This work is a preprint and has not yet been peer-reviewed.

All authors have read and approved this version of the manuscript for pre-print.

Author Rajiv Ranganathan @rrangana1 can be reached on Twitter.

This work can be cited as: Ranganathan, R., Tomlinson, A., Lokesh, R., Lin, T., Patel, P. (2019, September 9). A tale of too many tasks: Fragmentation of tasks in motor learning and a call for model task paradigms. https://doi.org/10.31236/osf.io/2zsgj studies with a behavioral emphasis. For the sake of this review, we included a study in our analysis if (i) there was a focus on measurement of performance during a period of practice, (ii) there were at least two a priori defined groups in a between-subject design which were compared on the same task, and (iii) the population of focus was unimpaired adults. Overall, 64 papers were included based on these criteria.

For each study, we examined the task used and classified it into one of six categories adaptation, applied, coordination, sequence, tracking, and variability. The broad rules for each of these categories are specified in Table 1. Although these categories were not always mutually exclusive, for the sake of this review, we classified each study into only one category. When there were conflicts on the categorization, the authors resolved such conflicts through discussion.

We then examined the actual tasks used in each category to examine if these studies used the same experimental paradigm. For example, when reaching was used as a task in the 'adaptation category', we compared experimental parameters such as the type of perturbation, the amplitude of the reach, the number of targets, etc. to examine if the protocols used were the same. We coded features only based on the task itself, and did not include protocol information (such as the number of practice trials, instructions to the 
participant, time between trials etc.). Based on this information, a task was classified as 'unique' if it did not match any other task in its category. In addition to the task, sample sizes used were also extracted. This information is summarized in Table 2.

We found that a majority of the studies on motor learning were on adaptation $(36 \%)$, followed by coordination $(17 \%)$, sequence learning $(16 \%)$, variability $(12 \%)$, tracking (11\%), and applied tasks (8\%) (Fig 1A). Group sample sizes were typically in the range of $10-16$ participants (25th to 75 th percentile) (Fig 1B). Critically, we found that out of the 64 studies reviewed, 62 were unique tasks, a fragmentation of $97 \%$ (Fig 1C). In fact, of the two matches found, one was from the same group of authors, and the second was a standard commercially available device. These results highlight the high degree of fragmentation in task paradigms in the field.

\subsection{Review of golf putting studies}

To further examine how task fragmentation occurs even when researchers seemingly rely on the same task, we performed a second analysis where we focused on studies that all used a relatively common task - golf putting. We used the search phrases 'golf' and 'motor learning' in Web of Science, and studies from 2013-2018 were examined. The same inclusion criteria were used as before, and we only focused on putting studies (e.g. studies on the golf swing or chip shots were not included). Information about the putt distance, target type, target size, the surface type, and the scoring system were extracted (Table 3 ). The scoring system, while not strictly part of the task itself, was included as a factor because it has a direct influence on how results from different studies can be interpreted relative to each other. Overall 22 studies were selected.

Once again, results showed that even within the context of the same task, studies used a variety of different putt distances (Fig 1D). When several studies used the same putting distance, they were usually either because they came from the same group of authors, or they varied in other parameters such as the hole type, diameter, and the scoring system (Table 3). Even though such differences may seem trivial at first glance, they can create important differences between studies. For example, the use of an actual hole (as opposed to a circle) increases ecological validity but adversely affects estimation of error and variability. This is because a range of ball velocities will land in the hole and be 'compressed' as zero error. Similarly, from a scoring standpoint, discretizing a continuous error measure such as the distance of the ball from the center of the target into measures such as the number of successful putts or a points system has the potential to significantly distort learning curves [2]. Finally, other information was incomplete to the extent that it would be difficult to perform a direct replication. For example, in the putting surface, the term 'synthetic' or 'artificial' green was used in several papers; however, only two papers mentioned the 'speed' of the green used, which is a critical variable for replication.
These results highlight that even when the same general task is chosen, there is still a high degree of fragmentation in tasks across studies.

\section{Consequences of task fragmenta- tion}

\subsection{Theoretical consequences}

From a theoretical standpoint, the fragmentation of tasks across studies makes every finding an 'island' and hampers the cumulative progress of science, where researchers can replicate the findings and then build off of previous research [3]. This issue is critical in light of the recent 'replication crisis', where well-known effects in many fields have either failed to replicate or have had smaller effects than once originally assumed [4,5]. Although one argument for using different tasks is that they can be useful in testing the generality of theories and hypotheses in different contexts, the utility of exclusively relying on such 'conceptual replications' has been challenged because it is subject to confirmation bias [6]. In other words, if the results of the original and the conceptual replication agree, then it is taken as evidence of the generality of the effect; however, if the results of the original study and the conceptual replication differ (i.e. the replication 'failed'), then these differences are directly attributed to the changed task parameters in the conceptual replication. This leads to a situation where the robustness of the original finding can never be questioned. Moreover, it has been argued that even when such conceptual replications fail, current incentive structures at many journals make the likelihood of publishing these results low, leading to a biased literature [7].

This issue of being able to replicate the same study (i.e. a direct replication) is especially important in the context of motor learning because of the recognition of the role of tasks and task constraints in determining behavior $[8,9]$. Given that tasks can vary along several dimensions, it is perhaps not surprising that many of these dimensions have been used as explanations for discrepancies in results across studies e.g., practice spacing effects are affected by whether tasks are discrete or continuous [10], frequency of augmented feedback effects are affected by whether tasks are simple or complex [11], and sleep consolidation effects are affected by whether the tasks involve sequence learning or adaptation [12]. Although these task dimensions certainly play an important role, it is also important to recognize that the true effect that they play cannot be fully understood without ensuring the robustness of the original findings through direct replications.

\subsection{Methodological consequences}

In addition to theoretical consequences, there are also methodological consequences of task fragmentation. Here, we focus on three primary consequences of such fragmentation - (i) arbitrariness in choice of task parameters, (ii) arbitrariness in choice of sample size, and (iii) inability to 
A

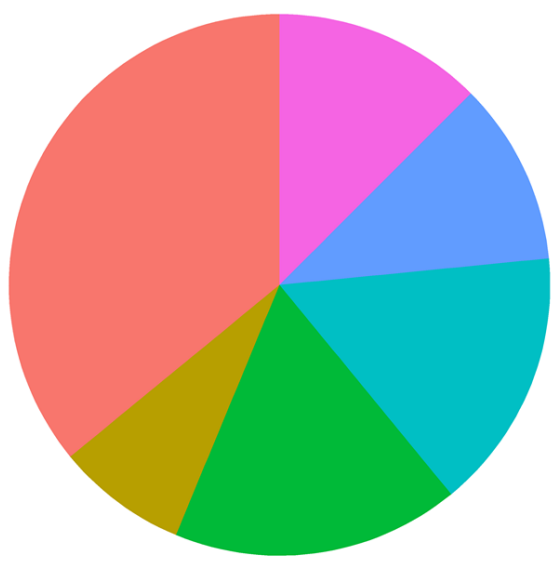

Total articles reviewed $(\mathrm{N}=64)$ Adaptation $(n=23)$ Coordination $(n=11)$ Tracking $(n=7)$ Applied $(n=5)$

\section{C}

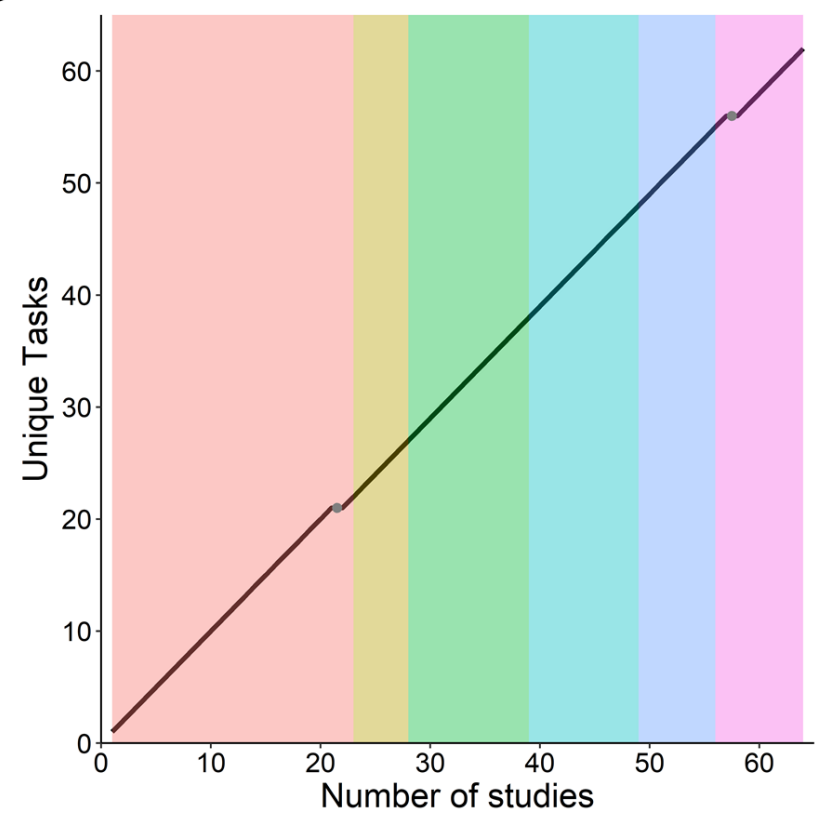

B

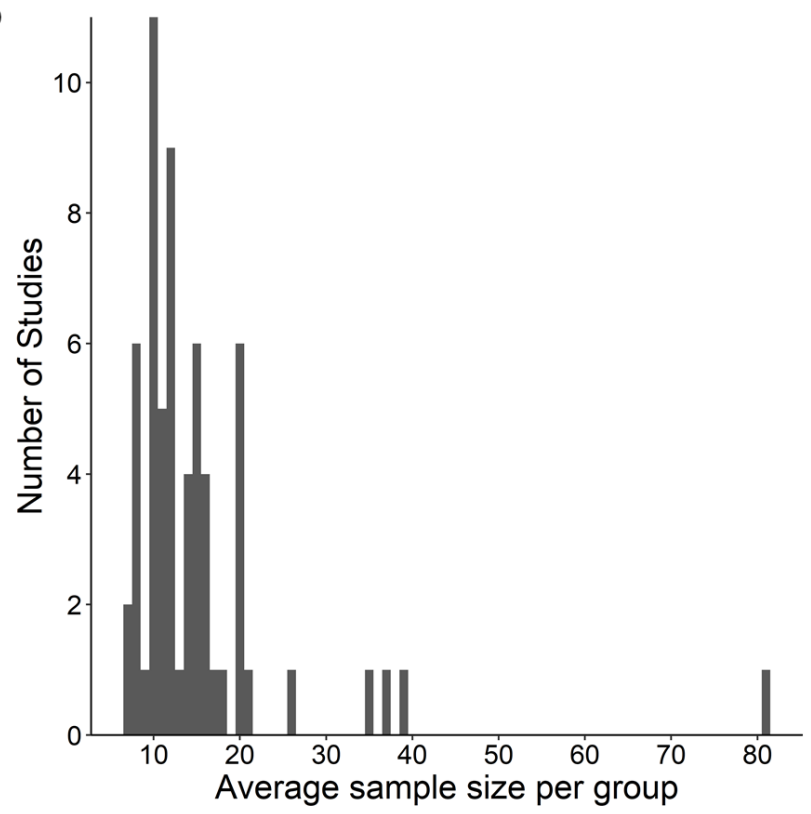

D

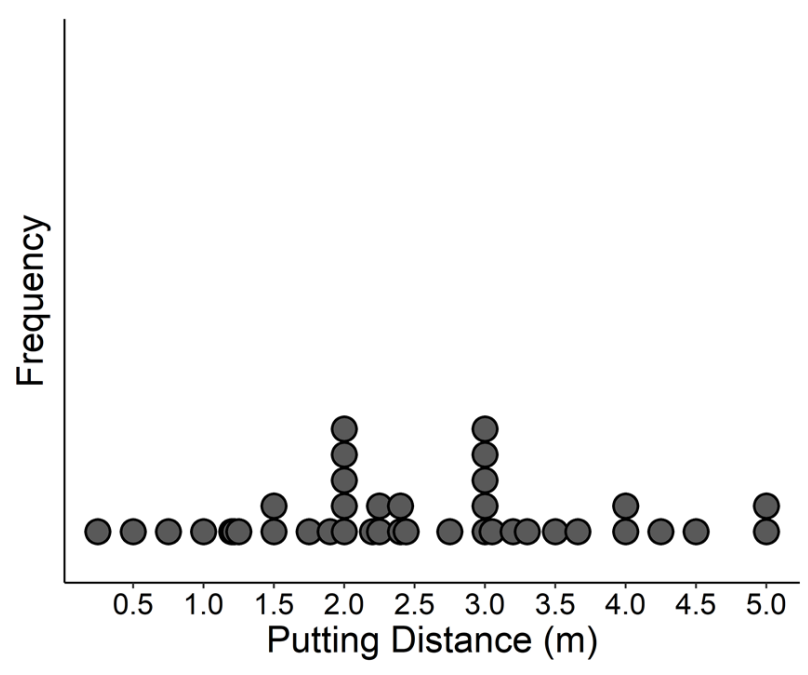

Figure 1: Fragmentation of task paradigms in motor learning. (A) Distribution of task categories across all studies studies were divided into six categories based on the criteria shown in Table 1. (B) Distribution of sample size/group across all studies, The majority of studies ranged between 10-16 participants in a group. (C) Plot of the number of studies reviewed in the current paper on the x-axis against the number of uniquely different tasks on the $\mathrm{y}$-axis. The almost perfect diagonal line indicates that there was little to no overlap in tasks between studies across all six categories, (D) Variability in putt distance across golf putting tasks shows fragmentation of task paradigms even within the same task. When the same putting distance was used across studies, they were usually because they were from the same set of authors, or they varied in other parameters such as the hole type, the surface, and the scoring system. 
compare magnitudes of effects across different manipulations.

\subsubsection{Arbitrariness in task parameters}

At the experimental design stage, the use of a new task poses a challenge for the experimenter because it requires making choices about several task parameters that are critical to the experiment without sufficient information. For example, in a motor learning study, a common parameter that is a critical part of the experiment is the practice duration; yet this choice is rarely explicitly justified. Instead, researchers are likely to choose these values through a combination of unpublished pilot testing, applying rules of thumb based on other published studies, and convenience (e.g., choosing the shortest duration possible). These arbitrary choices can greatly limit the generalization of motor learning findings to the real-world - for example, in spite of the seemingly diverse range of tasks used, very few studies focus on the period after extended practice, when an effective performance plateau has been reached [13].

An even bigger challenge is the choice of the experimental manipulation itself. Typically, studies in motor learning involve a between-group manipulation of an independent variable with the experimenter having to decide on what the values of these variable are. For example, a study on variable practice may use a throwing task and compare two groups - a 'constant' group that always practices throws to a target from the same distance, and a 'variable' group that practices throws to different distances [14]. However, the critical parameter choice of how much variability the variable group experiences can have a major influence on the observed results [15]. This is because most practice strategies (e.g., practice variability, practice spacing, feedback frequency) are likely to be 'non-monotonic' with respect to their influence on learning - i.e., there is an optimal level that maximizes learning, and there is a decrease in the amount of learning both above and below this optimal level [16].

When the choice of this task parameter is made without sufficient information, it means that the experimenter does not know where the groups lie on this non-monotonic function (Fig 2). As a result, even when the underlying effect of a manipulation is consistent across studies, different studies may get seemingly 'contradictory' results simply because they are sampling at different points of this function (Fig 2A-C). To further compound this problem, when studies use different tasks, these discrepancies in results caused by variations in sampling may get incorrectly attributed to the task itself. One potential solution for this problem is to characterize a full 'dose-response curve' for each task and task manipulation by increasing the number of groups and sampling across the full parameter range (Fig 2D). However, given the amount of effort needed to establish this dose-response curve, doing it for every new task would likely be impractical. These highlight the need for fewer tasks, and more data on these tasks to make more informed decisions on these task parameters.

\subsubsection{Arbitrariness in sample size planning}

Another key parameter choice in experimental design is the sample size. Several reviews have emphasized the need for a priori sample size planning, because the lack of adequate power stemming from small sample sizes can greatly reduce the reliability of the findings in the literature [17]. However, just like the task parameters, sample size planning tends to become arbitrary when a new task is used. Consistent with a prior review of studies in motor learning [18], sample sizes seen in our current review were around the 10-16/group (25th-75th percentile), regardless of the effect being studied. These sample sizes suggest that they are likely driven by heuristics for meeting a "publication threshold' for journals.

The major barrier to doing a priori sample size planning in a new task is the lack of information on the expected effect size, or alternatively the 'smallest effect size of interest' [19]. Effect sizes estimated from small samples of pilot data are not reliable [20], and even meta-analytic estimates of effect size in motor learning seem to suffer from issues of small sample size and publication bias [18]. Moreover, as mentioned in the task parameters section, heterogeneity in the effect size across different studies could also be driven by factors such as variation in the tasks and task parameters. These issues again point to the need for more data on fewer tasks to obtain reliable estimates of effect sizes, and thereby determine an appropriate sample size.

\subsubsection{Uninformative magnitude of effects}

Finally, if motor learning studies are to be of relevance to the real world (and not just mere demonstrations of effects), the goal is not only to detect 'if' there is an effect of an intervention, but also to estimate the size of the effect - i.e., what can cause the 'biggest' effect. A literature with fragmented tasks is detrimental to this goal because it prevents any relative comparisons of magnitude of effects across different experimental manipulations. For example, how do we compare the relative benefits of manipulations like practice spacing, variable practice, or self-controlled practice if each of these manipulations uses a different task with different dependent variables? Although this might seem like an 'apples to oranges' comparison, knowing at least the effective range of performance improvements for each of these manipulations is critical to determining an effective training paradigm in the real world. For example, in rehabilitation studies, this comparison between different types of therapies (e.g., robotics vs. conventional therapy) is routinely done by comparing the improvement in movement impairment measured on a common scale (e.g. the Fugl-Meyer score) [21] . However, in motor learning studies, this common scale requires the use of the same task because (i) unlike measures of movement impairment, measures of motor learning, by definition, are specific to the task, and (ii) using standardized effect sizes (e.g. Cohen's d) to make comparisons across tasks can be problematic because factors other than the mean difference, such as sample variability influence these effect sizes [22]. These issues 

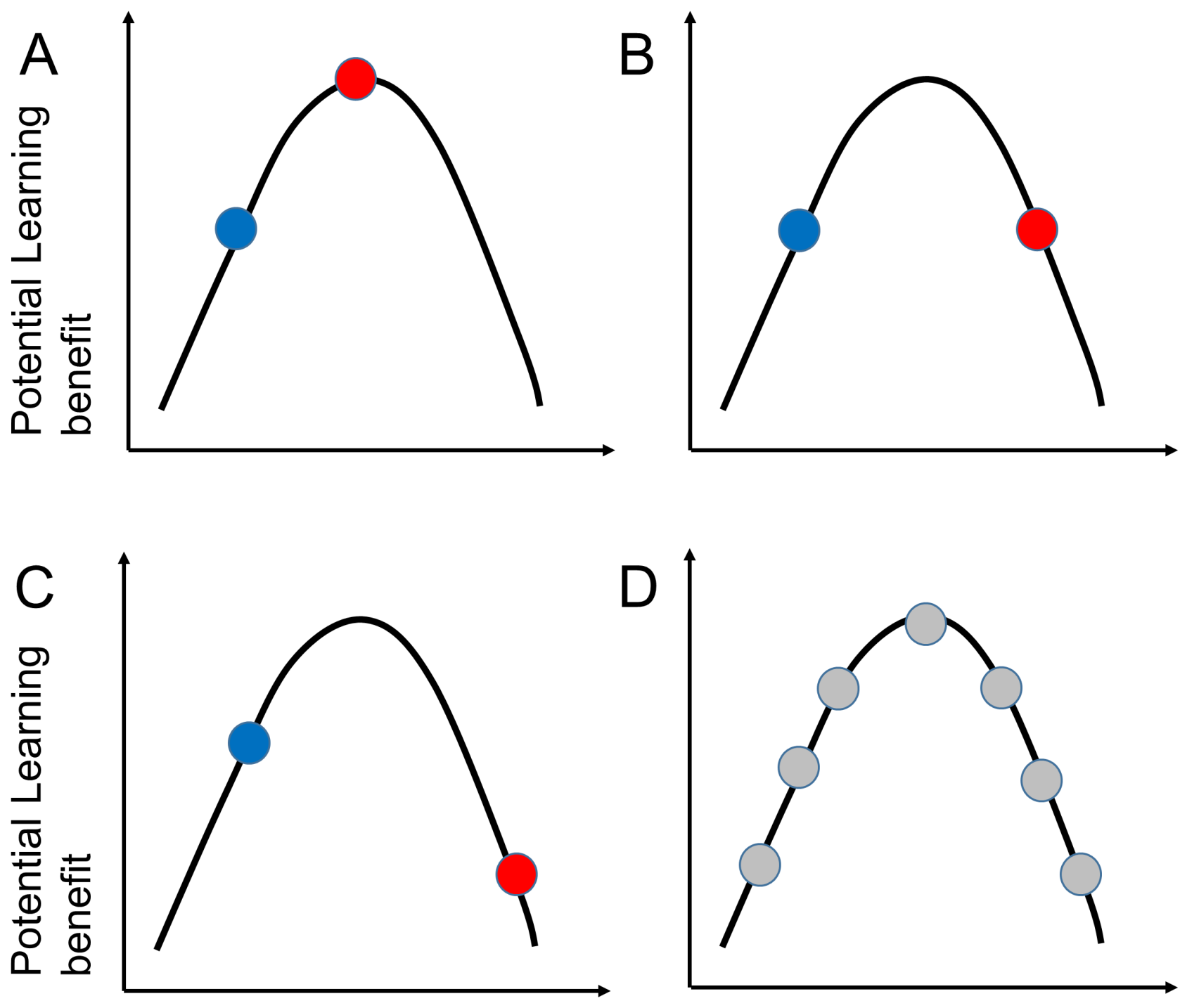

\section{Task parameter}

\section{Task parameter}

Figure 2: Arbitrary selection of task parameters can lead to seemingly contradictory results. Considering that the effect of many manipulations in motor learning (e.g., variability, spacing, feedback frequency etc.) are likely non-monotonic, task parameter selection becomes critical. For example, in a simple two group design (the 'low' group in blue, and the 'high' group in red), even though the underlying relation is the same in all cases, arbitrary selection of the task parameter can lead to (A) the high group learning more than the low group, (B) no difference between groups, or (C) the low group learning more than the high group. (D) A dose-response curve with more groups avoids this issue by providing a complete description of the non-monotonic relation, however given the much larger sample size required, establishing such dose-response curves becomes impractical when each study uses a different task. 
highlight that for comparing magnitudes of effects between different manipulations, there is a need for common tasks (and associated dependent variables), where improvements in performance can be directly compared across studies in raw units of measurement (e.g., error measured in centimeters).

\section{A call for model task paradigms}

In light of these issues, we feel there is a necessity to create a few 'model' task paradigms for motor learning studies. These model task paradigms could serve as a common testbed for several studies on motor learning and labs all over the world could run identical (or nearly identical) experiments using these paradigms. This proposal is analogous to the study of model organisms in related fields like biology and neuroscience. In such model systems, there is a recognition that it is not fully possible to study all possible variations, but that the knowledge gained from systematic study of a few carefully chosen representative systems can provide important insights for the field.

\subsection{Characteristics of model task paradigms}

What would be the characteristics of model task paradigms used for motor learning? Although a number of factors may be involved in determining this (e.g., whether the timescale of learning is feasible, whether the difficulty is appropriate so that a majority of the participants can learn the task etc.), our view is that a task chosen for a model paradigm would have to score high at least on two dimensions: (a) representativeness and (b) replication.

The 'Representativeness' dimension measures how well the paradigm addresses the scientific question of interest. Tasks that score high on representativeness would include typical features such as high internal validity, high ecological validity, and the ability to generalize to real-world tasks [23]. Given that motor learning likely involves distinct types of processes in the different categories specified in Table 1, it is likely that model tasks for each of these processes would also have to be distinct to directly address these specific processes. Importantly though, by specifying these model tasks at the level of these processes associated with learning (which are relatively few in number), researchers would be capable of reusing the tasks to address multiple research questions. For example, a model task of sequence learning could be used to address multiple varied research questions such as the role of sleep and consolidation (i.e. whether sleep enhances learning), contextual interference (i.e. whether random practice is superior to blocked practice), or the effect of self-controlled practice (i.e. whether having control of the practice sequence is superior to randomly practicing sequences).

The 'Replication' dimension measures how easy it is to replicate the paradigm in different labs, with access to potentially different resources. Tasks that score high on replication would involve tasks with low reliance on specialized equipment and the ability to obtain tight experimental control. For example, for a task involving control of variability, an underhand throw to a target would score higher on the replication dimension compared to a golf putt because it does not require a specific putter nor is it affected by environmental factors such as the friction between the ball and the surface. Similarly, a model task paradigm using inexpensive tools like webcam-based marker tracking [24] or markerless video tracking [25] would score higher on the replication dimension than tasks requiring the use of specialized expensive equipment because it is likely to be more easily replicated in more labs with access to relatively fewer resources.

Once an appropriate task is identified, the next step in making it a model task paradigm is to ensure sufficient transparency that other researchers can replicate and build off these results. This involves two steps - (a) the tasks are specified in enough detail that other groups can replicate the tasks as closely as possible, and (b) the data and analyses from these experiments are shared in a public repository so that the results from prior experiments can be combined and compared with results from future experiments. Practical guidelines for sharing of methods and data have been extensively reviewed in other domains [26,27]. Specifically in terms of motor learning, because of the richness and complexity of behavior possible, a particularly relevant solution is the use of video to help other researchers replicate the procedure more closely [28].

\subsection{Advantages of using model task paradigms}

The use of model task paradigms directly addresses the challenges raised in Section 3. First, from a theoretical standpoint, model task paradigms permit direct replications which increases the likelihood of finding effects that are robust. Second, by adopting a 'replicate and extend' strategy (i.e. the experiment involves direct replication of a previous experiment but also collects data on some new parameter values), data from the first few studies would effectively yield 'dose-response curves' (such as those shown in Fig 2D) that can provide important information about designing task parameter values for experimental manipulations. In fact, the use of model task paradigms opens the door for large scale studies across the globe that multiple labs can collaborate on - see for e.g. Psych Science Accelerator [29]. These approaches may allow answering questions with large sample sizes that are currently not being investigated (e.g. individual differences) because they are beyond the scope of a single lab. Third, the presence of openly available data on a single task paradigm can produce more reliable estimates of effect sizes, and also facilitate discussion on what theoretically meaningful effect sizes are. This information, analogous to the minimally clinical important difference (MCID) used in rehabilitation studies, is critical to making the distinction between 'statistically significant' and 'meaningful' results. Finally, using model task paradigms across different types of manipulations will al- 
low direct comparisons in terms of raw effect sizes between different types of practice strategies, allowing practitioners with a good understanding of the relative utility of these strategies.

Beyond addressing these challenges, another feature of using model task paradigms is that they can effectively constrain 'researcher degrees of freedom' [30]. Although the term has been used to describe how undisclosed flexibility in data collection and analyses (such as flexibility in sample size or choosing among dependent variables) can dramatically increase the false positive rate, the same issue also arises in the context of flexibility in task paradigms. For example, early studies on the role of augmented information in motor learning often chose task paradigms with extremely poor intrinsic information, such as drawing a line of a specified length. As a result, the role of augmented information was overrated in these tasks because it was often the only way participants could know what the task goal was [31]. Relatedly, the measurement of learning in these contexts has also used somewhat artificial situations such as No-KR tests, which often involve blindfolding participants from seeing the natural outcome of their actions [32]. Such criticisms have raised an important question of how relevant principles derived from simple tasks are to real-world learning $[11,32]$. Because model task paradigms are common only to broad themes in motor learning, and not at the level of individual research questions, they can effectively constrain flexibility in tweaking of the task (intentional or unintentional) because the task and analyses are largely fixed in advance.

Last but not least, the use of model task paradigms also allows 'data-driven' discovery that could complement the dominant 'hypothesis-driven' approach in motor learning. The availability of relatively large data sets on a few standardized tasks could yield answers to questions that were not originally the focus of the work. An example of this in the motor learning has been the DREAM database [33]. Originally established as a collection of different experiments on reaching, data from these experiments were subsequently used to address a question about variability and rate of motor learning [34]. In addition, these large data sets can also help serve to generate and test new theories or models of learning, as any new proposed theory or model at least needs to adequately accommodate for these data before making other testable predictions for future experiments.

\subsection{Costs to using model task paradigms}

From a practical standpoint, there is a cost in terms of the initial effort involved in developing model task paradigms compared to the status quo. Potential factors that drive this effort are (a) more careful consideration of tasks, (b) precise specification of associated measurement, (c) the use of larger sample sizes with more groups, and (d) the effort involved in making data and resources openly available. However, we think that benefits are cumulative, with subsequent studies becoming much easier to plan and execute because it would allow investigators to skip over repeated pilot-testing phases, and use previously published data to make informed estimates about new experiments. Second, there is a potential risk of duplication if two research groups run the same experiment using the same model task. However, with the rising popularity of pre-prints and formats such as registered reports which allow for 'results-blind' acceptance $[35,36]$, we believe that such concerns can be overcome.

More broadly for the field, there is a potential concern that model task paradigms may narrow the impact or generality of the field by decreasing the diversity of phenomena being studied. This concern has been expressed in the context of model organisms in biology [37] and it is important not to fall back on the 'easy' route of only studying questions that can be answered using existing model task paradigms. However, given that motor learning is currently at the other extreme with excessive fragmentation, we think that this concern, is at least for the moment, not a major one. In fact, as model task paradigms emerge for different themes, they may in fact actually help increase the diversity of problems studied by more clearly revealing which issues have received less attention.

It is also perhaps worth re-iterating that model task paradigms are not meant to be a requirement for every experiment. Research questions at either extreme of the theoretical-applied spectrum are likely to continue to use customized tasks that suit their purpose. On the theoretical side, studies may involve a very specific manipulation (e.g., using a robotic exoskeleton to perturb a single joint) that requires the use of a task which does not fall into one of the model tasks. Similarly, on the applied side, there will always be a need for applied studies where the task itself is critical to the research question being answered (e.g., improving surgical technique). However, for the vast majority of studies in the middle of this spectrum, which have some flexibility in the choice of tasks, model task paradigms may provide a solution to the current level of fragmentation. These paradigms will also continue to evolve with greater theoretical understanding and improvements in measurement tools. Ultimately the success of any model task paradigm will depend on how other researchers in the field see its value, both in terms of the insights it generates, and in terms of how these insights generalize to the real world.

\section{Conclusion}

In his seminal paper on motor learning, Jack Adams [38] criticized the use of real-world tasks saying that they resulted in 'disconnected pockets of data.. that was unsuitable for the development of general scientific principles'. However, with the current level of fragmentation, it is probably fair to say that the same problem also exists even with laboratory tasks in motor learning. While we speculate that there may be a number of factors that drive this fragmentation - incentives for novelty over replication, academic 'traditions' that are handed down from mentors to 
graduate students, or even seemingly mundane issues like the availability of space or equipment - we suggest that it is important for research efforts to coalesce around a few model task paradigms for a more robust science that researchers in the field can build upon.

\section{Acknowledgment}

The authors thank Dr. Chandramouli Krishnan for his comments on a previous version of this manuscript. This material is based upon work supported by the National Science Foundation under Grant No. 1823889.

\section{References}

1. Mischel, W. (2008). The Toothbrush Problem. APS Obs. 21. Available at: https://www.psychologicalscience.org/observer/thetoothbrush-problem [Accessed April 4, 2019].

2. Bahrick, H.P., Fitts, P.M., and Briggs, G.E. (1957). Learning curves; facts or artifacts? Psychol. Bull. 54,255268 .

3. Zwaan, R.A., Etz, A., Lucas, R.E., and Donnellan, M.B. (2018). Making replication mainstream. Behav. Brain Sci. 41, e120.

4. Camerer, C.F., Dreber, A., Holzmeister, F., Ho, T.H., Huber, J., Johannesson, M., Kirchler, M., Nave, G., Nosek, B.A., Pfeiffer, T., et al. (2018). Evaluating the replicability of social science experiments in Nature and Science between 2010 and 2015. Nat. Hum. Behav. 2, 637.

5. Open Science Collaboration (2015). Estimating the reproducibility of psychological science. Science 349, $\operatorname{aac} 4716$.

6. Chambers, C.D. (2017). The Seven Deadly Sins of Psychology (Princeton, NJ: Princeton University Press).

7. Pashler, H., and Harris, C.R. (2012). Is the Replicability Crisis Overblown? Three Arguments Examined. Perspect. Psychol. Sci. 7, 531536.

8. Newell, K.M. (1986). Constraints on the development of coordination. In Motor development in children: Aspects of coordination and control, M. G. Wade and H. T. A. Whiting, eds. (Nijhoff).

9. Newell, K.M. (1989). On task and theory specificity. J. Mot. Behav. 21, 9296.

10. Lee, T.D., and Genovese, E.D. (1989). Distribution of Practice in Motor Skill Acquisition: Different Effects for Discrete and Continuous Tasks. Res. Q. Exerc. Sport 60, 5965.
11. Wulf, G., and Shea, C.H. (2002). Principles derived from the study of simple skills do not generalize to complex skill learning. Psychon Bull Rev 9, 185211.

12. Doyon, J., Korman, M., Morin, A., Dostie, V., Tahar, A.H., Benali, H., Karni, A., Ungerleider, L.G., and Carrier, J. (2009). Contribution of night and day sleep vs. simple passage of time to the consolidation of motor sequence and visuomotor adaptation learning. Exp. Brain Res. 195, 1526.

13. Hasson, C.J., Zhang, Z., Abe, M.O., and Sternad, D. (2016). Neuromotor Noise Is Malleable by Amplifying Perceived Errors. PLoS Comput. Biol. 12, e1005044.

14. Kerr, R., and Booth, B. (1978). Specific and varied practice of motor skill. Percept. Mot. Skills 46, 395401.

15. Cardis, M., Casadio, M., and Ranganathan, R. (2018). High variability impairs motor learning regardless of whether it affects task performance. J. Neurophysiol. 119, 3948.

16. Guadagnoli, M.A., and Lee, T.D. (2004). Challenge Point: A Framework for Conceptualizing the Effects of Various Practice Conditions in Motor Learning. J. Mot. Behav. 36, 212224.

17. Button, K.S., Ioannidis, J.P.A., Mokrysz, C., Nosek, B.A., Flint, J., Robinson, E.S.J., and Munaf, M.R. (2013). Power failure: why small sample size undermines the reliability of neuroscience. Nat. Rev. Neurosci. 14, 365376.

18. Lohse, K., Buchanan, T., and Miller, M. (2016). Underpowered and overworked: Problems with data analysis in motor learning studies. J. Mot. Learn. Dev. 4, 3758 .

19. Lakens, D., Scheel, A.M., and Isager, P.M. (2018). Equivalence Testing for Psychological Research: A Tutorial. Adv. Methods Pract. Psychol. Sci. 1, 259269 .

20. Albers, C., and Lakens, D. (2018). When power analyses based on pilot data are biased: Inaccurate effect size estimators and follow-up bias. J. Exp. Soc. Psychol. $74,187195$.

21. Lo, A.C., Guarino, P.D., Richards, L.G., Haselkorn, J.K., Wittenberg, G.F., Federman, D.G., Ringer, R.J., Wagner, T.H., Krebs, H.I., Volpe, B.T., et al. (2010). Robot-assisted therapy for long-term upperlimb impairment after stroke. N Engl J Med 362, 177283.

22. Baguley, T. (2009). Standardized or simple effect size: what should be reported? Br. J. Psychol. Lond. Engl. 1953 100, 603617. 
23. Pinder, R.A., Davids, K., Renshaw, I., and Arajo, D. (2011). Representative Learning Design and Functionality of Research and Practice in Sport. J. Sport Exerc. Psychol. 33, 146155.

24. Krishnan, C., Washabaugh, E.P., and Seetharaman, Y. (2015). A low cost real-time motion tracking approach using webcam technology. J. Biomech. 48, 544548 .

25. Mathis, A., Mamidanna, P., Cury, K.M., Abe, T., Murthy, V.N., Mathis, M.W., and Bethge, M. (2018). DeepLabCut: markerless pose estimation of userdefined body parts with deep learning. Nat. Neurosci. 21,12811289 .

26. Gorgolewski, K.J., and Poldrack, R.A. (2016). A Practical Guide for Improving Transparency and Reproducibility in Neuroimaging Research. PLOS Biol. 14, e1002506.

27. Klein, O., Hardwicke, T.E., Aust, F., Breuer, J., Danielsson, H., Mohr, A.H., Ijzerman, H., Nilsonne, G., Vanpaemel, W., and Frank, M.C. (2018). A Practical Guide for Transparency in Psychological Science. Collabra Psychol. 4, 20.

28. Gilmore, R.O., and Adolph, K.E. (2017). Video can make behavioural science more reproducible. Nat. Hum. Behav. 1, 0128.

29. Moshontz, H., Campbell, L., Ebersole, C.R., IJzerman, H., Urry, H.L., Forscher, P.S., Grahe, J.E., McCarthy, R.J., Musser, E.D., Antfolk, J., et al. (2018). The Psychological Science Accelerator: Advancing Psychology Through a Distributed Collaborative Network. Adv. Methods Pract. Psychol. Sci. 1,501515 .
30. Simmons, J.P., Nelson, L.D., and Simonsohn, U. (2011). False-positive psychology: undisclosed flexibility in data collection and analysis allows presenting anything as significant. Psychol Sci 22, 135966.

31. Swinnen, S.P. (1996). Information feedback for motor skill learning: A review. Adv. Mot. Learn. Control, 3766 .

32. Russell, D.M., and Newell, K.M. (2007). On No-KR tests in motor learning, retention and transfer. Hum Mov Sci 26, 15573.

33. Walker, B., and Kording, K. (2013). The Database for Reaching Experiments and Models. PLOS ONE 8, e78747.

34. He, K., Liang, Y., Abdollahi, F., Fisher Bittmann, M., Kording, K., and Wei, K. (2016). The statistical determinants of the speed of motor learning. PLoS Comput Biol 12, e1005023.

35. Caldwell, A., Vigotsky, A.D., Nuckols, G., Boardley, I., Schmidt, J., Tenan, M., Skarabot, J., Radel, R., Naughton, M., Schoenfeld, B.J., et al. (2019). Moving Sport and Exercise Science Forward: A Call for the Adoption of More Transparent Research Practices (SportRxiv) Available at: https://osf.io/fxe7a [Accessed July 16, 2019].

36. Chambers, C.D. (2013). Registered reports: a new publishing initiative at Cortex. Cortex, 49, 609610.

37. Yartsev, M.M. (2017). The emperors new wardrobe: Rebalancing diversity of animal models in neuroscience research. Science 358, 466469.

38. Adams, J.A. (1971). A closed-loop theory of motor learning. J. Mot. Behav. 3, 111150. 
Table 1. Definition of task categories.

\begin{tabular}{|c|c|c|c|}
\hline $\begin{array}{l}\text { Task } \\
\text { Category }\end{array}$ & $\begin{array}{l}\text { Process involved in learning of } \\
\text { task }\end{array}$ & Typical dependent variable(s) & Example \\
\hline Adaptation & $\begin{array}{l}\text { Responding to perturbations of } \\
\text { typically well-learned movements }\end{array}$ & Deviation from baseline behavior & $\begin{array}{l}\text { Visuomotor } \\
\text { rotation }\end{array}$ \\
\hline Applied & $\begin{array}{l}\text { Production of movement responses } \\
\text { in 'real-world' situations that may } \\
\text { involve a combination of processes }\end{array}$ & Task-dependent & $\begin{array}{l}\text { Penalty kicks in } \\
\text { soccer }\end{array}$ \\
\hline Coordination & $\begin{array}{l}\text { Production of spatiotemporal pattern } \\
\text { involving more than a single degree } \\
\text { of freedom (limbs, joints, muscles) }\end{array}$ & $\begin{array}{l}\text { Coordination measures that capture } \\
\text { relative motion between the degrees of } \\
\text { freedom, dimensionality reduction } \\
\text { techniques }\end{array}$ & $\begin{array}{l}\text { Bimanual } \\
\text { coordination }\end{array}$ \\
\hline Sequence & $\begin{array}{l}\text { Production of a sequence of several } \\
\text { movement responses }\end{array}$ & Speed, errors, reaction time & Key pressing \\
\hline Tracking & $\begin{array}{l}\text { Production of a desired } \\
\text { spatiotemporal pattern that is 'time } \\
\text { varying' }\end{array}$ & $\begin{array}{l}\text { Deviation between the target pattern } \\
\text { and the actual }\end{array}$ & $\begin{array}{l}\text { Tracking a } \\
\text { moving target on } \\
\text { a screen }\end{array}$ \\
\hline Variability & $\begin{array}{l}\text { Production of a 'steady-state' task } \\
\text { performance level over time or trials }\end{array}$ & Variability across time or trials & $\begin{array}{l}\text { Throwing a ball } \\
\text { to a target }\end{array}$ \\
\hline
\end{tabular}


Table 2. Review of motor learning studies from selected journals in 2017-2018

\begin{tabular}{|c|c|c|c|c|c|c|}
\hline Authors & Category & Task & Task notes & Sample Size & $\begin{array}{l}\text { Sample } \\
\text { Size per } \\
\text { Group } \\
\end{array}$ & $\begin{array}{l}\text { Unique } \\
\text { Task } \\
(\mathbf{Y} / \mathbf{N})\end{array}$ \\
\hline $\begin{array}{l}\text { Couth et } \\
\text { al.[39] }\end{array}$ & Adaptation & Grasping & $\begin{array}{l}\text { Grasping haptic blocks } \\
\text { of different lengths } \\
\text { with vision-haptic } \\
\text { conflict }\end{array}$ & 48 (2 groups) & 24 & Y \\
\hline $\begin{array}{l}\text { Mcgregor et } \\
\text { al.[40] }\end{array}$ & Adaptation & Reaching & $\begin{array}{l}\text { FF curl k=14 Ns/m. } \\
\text { Amplitude } \\
\text { unspecified, Timing } \\
375+/-100 \mathrm{~ms}, 1 \text { target }\end{array}$ & 78 (3 groups) & 26 & $\mathrm{Y}$ \\
\hline $\begin{array}{l}\text { McGregor } \\
\text { and Gribble } \\
{[41]}\end{array}$ & Adaptation & Reaching & $\begin{array}{l}\text { FF curl k=14 Ns/m. } \\
\text { Amplitude } 15 \mathrm{~cm} \text {, } \\
\text { Timing } 450-550 \mathrm{~ms}, 1 \\
\text { target }\end{array}$ & 30 (2 groups) & 15 & $\mathrm{Y}$ \\
\hline $\begin{array}{l}\text { McKenna et } \\
\text { al. [42] }\end{array}$ & Adaptation & Reaching & $\begin{array}{l}\text { FF curl } \mathrm{k}=15 \mathrm{Ns} / \mathrm{m} . \\
\text { Amplitude } 10 \mathrm{~cm} \text {, } \\
\text { Peak vel between } \\
0.25-0.35 \mathrm{~m} / \mathrm{s} \text {, time < } \\
750 \mathrm{~ms}, 1 \text { target }\end{array}$ & 84 (6 groups) & 14 & $\mathrm{Y}$ \\
\hline $\begin{array}{l}\text { Milner et } \\
\text { al.[43] }\end{array}$ & Adaptation & Reaching & $\begin{array}{l}\text { FF curl } \mathrm{k}=15 \mathrm{Ns} / \mathrm{m} \text {. } \\
\text { Amplitude } 25 \mathrm{~cm} \text {, } \\
\text { Timing } 600+/-50 \mathrm{~ms} \text {, } \\
2 \text { targets }\end{array}$ & 28 (2 groups) & 14 & $\mathrm{Y}$ \\
\hline $\begin{array}{l}\text { Melendez- } \\
\text { Calderon et } \\
\text { al.[44] }\end{array}$ & Adaptation & Reaching & $\begin{array}{l}\text { FF curl } \mathrm{k}=25 \mathrm{Ns} / \mathrm{m} \text {, } \\
\text { Amplitude } 10 \mathrm{~cm} \text {, } \\
\text { Timing } 500-700 \mathrm{~ms}, 3 \\
\text { targets }\end{array}$ & $\begin{array}{l}\text { Exp1: } 7 \text { (1 } \\
\text { group); Exp2: } \\
30 \text { (3 groups) }\end{array}$ & 9.25 & $\mathrm{Y}$ \\
\hline $\begin{array}{l}\text { Kumar et } \\
\text { al.[45] }\end{array}$ & Adaptation & Reaching & $\begin{array}{l}\text { VMR } 30 \text { deg CW and } \\
\text { CCW, Amplitude } 13 \\
\mathrm{~cm}, 8 \text { targets ( } 45 \mathrm{deg} \\
\text { apart) }\end{array}$ & 48 (6 groups) & 8 & $\mathrm{Y}$ \\
\hline $\begin{array}{l}\text { Schmitz and } \\
\text { Bock [46] }\end{array}$ & Adaptation & Reaching & $\begin{array}{l}\text { VMR } 30 \text { deg CW and } \\
\text { CCW; Amplitude } \\
36 \mathrm{~cm}, 6 \text { visual and } \\
\text { auditory targets (+- } \\
6 / 18 / 30 \text { degs) }\end{array}$ & 36 (3 groups) & 12 & $\mathrm{Y}$ \\
\hline $\begin{array}{l}\text { Aiken et al. } \\
\text { [47] }\end{array}$ & Adaptation & Reaching & $\begin{array}{l}\text { VMR } 30 \text { deg CW, } \\
\text { Amplitude } 3 \mathrm{~cm}, 3 \\
\text { targets }(60,150 \text { and } \\
240 \mathrm{deg})\end{array}$ & 49 (4 groups) & 12.25 & $\mathrm{Y}$ \\
\hline $\begin{array}{l}\text { Holland et } \\
\text { al.[48] }\end{array}$ & Adaptation & $\begin{array}{l}\text { Reaching/Shoo } \\
\text { ting }\end{array}$ & $\begin{array}{l}\text { VMR } 15 \text { and } 25 \mathrm{deg} \\
\mathrm{CW} \text { and } \mathrm{CCW} ; \\
\text { Amplitude } 10 \mathrm{~cm} \text {, } \\
\text { 200-1000ms time, } 1 \\
\text { target }(90 \mathrm{deg})\end{array}$ & $\begin{array}{l}\text { Exp1: } 40(3 \\
\text { groups }) ; \operatorname{Exp} \\
2: 20(2 \\
\text { groups })\end{array}$ & 12 & $\mathrm{Y}$ \\
\hline $\begin{array}{l}\text { Canaveral et } \\
\text { al.[49] }\end{array}$ & Adaptation & $\begin{array}{l}\text { Reaching/Shoo } \\
\text { ting }\end{array}$ & $\begin{array}{l}\text { VMR } 15 \text { deg CCW; } \\
\text { Amplitude } 10 \mathrm{~cm}, 150 \\
\text { ms time, } 8 \text { targets ( } 45 \\
\text { degs starting from } \\
22.5 \text { ) }\end{array}$ & $\begin{array}{l}\text { Exp1: } 32(3 \\
\text { groups }) ; \text { Exp } \\
2: 23(2 \\
\text { groups })\end{array}$ & 11 & $\mathrm{Y}$ \\
\hline $\begin{array}{l}\text { Jiang et } \\
\text { al. }[50]\end{array}$ & Adaptation & $\begin{array}{l}\text { Reaching/Shoo } \\
\text { ting }\end{array}$ & $\begin{array}{l}\text { VMR } 30 \text { deg CCW, } \\
\text { Amplitude } 7 \mathrm{~cm}, \\
\text { timing } 100-400 \mathrm{~ms}, 1 \\
\text { target }\end{array}$ & $\begin{array}{l}192(16 \\
\text { groups })\end{array}$ & 12 & $\mathrm{Y}$ \\
\hline $\begin{array}{l}\text { Jalali et } \\
\text { al.[51] }\end{array}$ & Adaptation & $\begin{array}{l}\text { Reaching/Shoo } \\
\text { ting }\end{array}$ & $\begin{array}{l}\text { VMR } 30 \text { deg CCW, } \\
\text { Amplitude } 8 \mathrm{~cm},\end{array}$ & $\begin{array}{l}\text { Exp1: } 28(2 \\
\text { groups }) ; \operatorname{Exp} \\
2: 20(2\end{array}$ & 13.79 & $\mathrm{Y}$ \\
\hline
\end{tabular}




\begin{tabular}{|c|c|c|c|c|c|c|}
\hline & & & $\begin{array}{l}\text { timing of } 100-300 \mathrm{~ms} \text {, } \\
8 \text { targets }\end{array}$ & $\begin{array}{l}\text { groups); Exp } \\
\text { 3: } 27(2 \\
\text { groups); Exp } \\
\text { 4: } 24 \text { (2 } \\
\text { groups); Exp } \\
\text { 5: } 36 \text { (2 } \\
\text { groups); Exp } \\
\text { 6: } 32 \text { (2 } \\
\text { groups); } \\
\text { Exp7: 26 (2 } \\
\text { groups) }\end{array}$ & & \\
\hline $\begin{array}{l}\text { Leow et } \\
\text { al.[52] }\end{array}$ & Adaptation & $\begin{array}{l}\text { Reaching/Shoo } \\
\text { ting }\end{array}$ & $\begin{array}{l}\text { VMR } 30 \text { deg CW and } \\
\text { CCW, Amplitude } \\
9 \mathrm{~cm}, 8 \text { targets }\end{array}$ & $\begin{array}{l}\text { Exp 1A: } 14 \text { (1 } \\
\text { group); Exp } \\
\text { 1B: } 14 \text { (1 } \\
\text { group); Exp 2: } \\
36 \text { (3 groups); } \\
\text { Exp 3: } 10 \text { (1 } \\
\text { group) }\end{array}$ & 12.33 & $\mathrm{Y}$ \\
\hline $\begin{array}{l}\text { Song and } \\
\text { Smiley-Oyen } \\
{[53]}\end{array}$ & Adaptation & $\begin{array}{l}\text { Reaching/Shoo } \\
\text { ting }\end{array}$ & $\begin{array}{l}\text { VMR } 50 \text { deg CW, } \\
\text { Amplitude } 10 \mathrm{~cm} \text {, } \\
\text { Timing } 100-600 \mathrm{~ms}, 1 \\
\text { target }\end{array}$ & 44 (4 groups) & 11 & $\mathrm{Y}$ \\
\hline $\begin{array}{l}\text { Reilly and } \\
\text { Pettibone } \\
\text { [54] }\end{array}$ & Adaptation & Speech & $\begin{array}{l}5 \text { CVC (consonant- } \\
\text { vowel-consonant) } \\
\text { words with different } \\
\text { embedding of vowels }\end{array}$ & 40 (2 groups) & 20 & $\mathrm{Y}$ \\
\hline $\begin{array}{l}\text { Seidler et } \\
\text { al.[55] }\end{array}$ & Adaptation & Throwing & $\begin{array}{l}\text { Prism goggles - 40D; } \\
\text { dart throw from } 7 \mathrm{ft}\end{array}$ & 60 (4 groups) & 15 & $\mathrm{Y}$ \\
\hline $\begin{array}{l}\text { Cattan et } \\
\text { al.[56] }\end{array}$ & Adaptation & Tracking & $\begin{array}{l}\text { Delay adaptation, } \\
\text { Tracing ellipse and a } \\
\text { figure } 8 \text { pattern }\end{array}$ & $\begin{array}{l}20 \text { ( } 2 \text { groups) } \\
\text { in Exp } 1 ; 26 \\
\text { ( } 2 \text { groups) in } \\
\text { Exp } 2\end{array}$ & 11.5 & $\mathrm{Y}$ \\
\hline $\begin{array}{l}\text { French et } \\
\text { al.[57] }\end{array}$ & Adaptation & Walking & $\begin{array}{l}\text { Distorted visual } \\
\text { feedback of stride } \\
\text { length by upto } 9 \% \text {, } \\
\text { Treadmill Speed }-1.2 \\
\text { m/s. }\end{array}$ & $\begin{array}{l}\text { Exp 1: } 28(2 \\
\text { groups); Exp } \\
2: 6(1 \text { group })\end{array}$ & 11.33 & $\mathrm{Y}$ \\
\hline $\begin{array}{l}\text { Maeda et } \\
\text { al.[58] }\end{array}$ & Adaptation & Walking & $\begin{array}{l}\text { Prism goggles - 20D, } \\
\text { Precision walking task } \\
\text { across 6-m path }\end{array}$ & $\begin{array}{l}100(10 \\
\text { groups })\end{array}$ & 10 & $\mathrm{Y}$ \\
\hline $\begin{array}{l}\text { Hinkel- } \\
\text { Lipsker and } \\
\text { Hahn [59] }\end{array}$ & Adaptation & Walking & $\begin{array}{l}\text { Split-belt treadmill } \\
\text { with one limb }+/- \\
0.5 \mathrm{~m} / \mathrm{s} \text { of SSWS }\end{array}$ & 48 (6 groups) & 8 & $\mathrm{Y}$ \\
\hline $\begin{array}{l}\text { Hinkel- } \\
\text { Lipsker and } \\
\text { Hahn [60] }\end{array}$ & Adaptation & Walking & $\begin{array}{l}\text { Split-belt treadmill } \\
\text { with one limb }+/- \\
0.5 \mathrm{~m} / \mathrm{s} \text { of SSWS }\end{array}$ & 48 (3 groups) & 16 & $\mathrm{~N}$ \\
\hline Day et al.[61] & Adaptation & Walking & $\begin{array}{l}\text { Split-belt treadmill } \\
\text { with one limb at } 0.7 \text {, } \\
\text { one limb at } 1.4 \mathrm{~m} / \mathrm{s}\end{array}$ & 40 (4 groups) & 10 & $\mathrm{Y}$ \\
\hline Kim et al.[62] & Applied & Golf putting & $\begin{array}{l}2 \mathrm{~m}, 5 \mathrm{~m} \text { putts on real } \\
\text { green }\end{array}$ & 20 (2 groups) & 10 & $\mathrm{Y}$ \\
\hline $\begin{array}{l}\text { Navarro et } \\
\text { al.[63] }\end{array}$ & Applied & Penalty kicks & & 20 (2 groups) & 10 & $\mathrm{Y}$ \\
\hline $\begin{array}{l}\text { Chien and } \\
\text { Chen [64] }\end{array}$ & Applied & Petanque & & $\begin{array}{l}75 \text { ( } 2 \text { groups }) \\
37 / 38\end{array}$ & 37.5 & $\mathrm{Y}$ \\
\hline
\end{tabular}




\begin{tabular}{|c|c|c|c|c|c|c|}
\hline $\begin{array}{l}\text { Krajenbrink } \\
\text { et al. [65] }\end{array}$ & Applied & Slingerball & $\begin{array}{l}5 \mathrm{~m} \text { throw to a } 2 \mathrm{~m} \text { dia } \\
\text { target }\end{array}$ & 162 (2 groups) & 81 & $\mathrm{Y}$ \\
\hline Hebert [66] & Applied & $\begin{array}{l}\text { Speed cup } \\
\text { stacking }\end{array}$ & & 117 (3 groups) & 39 & $\mathrm{Y}$ \\
\hline Lin et al.[67] & Coordination & $\begin{array}{l}\text { Arm-Trunk } \\
\text { reaching }\end{array}$ & $\begin{array}{l}\text { Reaching for targets } \\
\text { with trunk motion }\end{array}$ & 48 (4 groups) & 12 & $\mathrm{Y}$ \\
\hline $\begin{array}{l}\text { Panzer et } \\
\text { al.[68] }\end{array}$ & Coordination & Bimanual & $\begin{array}{l}1: 2 \text { pattern using } \\
\text { forearms }\end{array}$ & 32 (4 groups) & 8 & $\mathrm{Y}$ \\
\hline $\begin{array}{l}\text { Bingham et } \\
\text { al.[69] }\end{array}$ & Coordination & Bimanual & $\begin{array}{l}90 \text { deg rel phase using } \\
\text { joysticks }\end{array}$ & 20 (2 groups) & 10 & $\mathrm{Y}$ \\
\hline $\begin{array}{l}\text { Dyer et } \\
\text { al.[70] }\end{array}$ & Coordination & \begin{tabular}{|l|} 
Bimanual \\
\end{tabular} & $\begin{array}{l}\text { Bimanual shape } \\
\text { tracking with music } \\
\text { feedback }\end{array}$ & 60 (3 groups) & 20 & $\mathrm{Y}$ \\
\hline $\begin{array}{l}\text { Cardis et al. } \\
\text { [71] }\end{array}$ & Coordination & Bimanual & $\begin{array}{l}\text { Throwing virtual puck } \\
\text { with both hands } \\
\text { toward a target }\end{array}$ & 50 (5 groups) & 10 & $\mathrm{Y}$ \\
\hline $\begin{array}{l}\text { Thorp et } \\
\text { al.[72] }\end{array}$ & Coordination & Bimanual & $\begin{array}{l}\text { Virtual reaching task } \\
\text { with IMUs }\end{array}$ & 16 (2 groups) & 8 & $\mathrm{Y}$ \\
\hline $\begin{array}{l}\text { Kimura et } \\
\text { al.[73] }\end{array}$ & Coordination & $\begin{array}{l}\text { Dual task of } \\
\text { isometric knee } \\
\text { extension and } \\
\text { elbow flexion }\end{array}$ & $\begin{array}{l}\text { Knee extension } \\
\text { required force } \\
\text { production; Reaction } \\
\text { time task with elbow }\end{array}$ & 45 (3 groups) & 15 & $\mathrm{Y}$ \\
\hline $\begin{array}{l}\text { Shuggi et } \\
\text { al.[74] }\end{array}$ & Coordination & $\begin{array}{l}\text { Head-control } \\
\text { reaching }\end{array}$ & $\begin{array}{l}\text { Reaching to targets } \\
\text { with a robot arm while } \\
\text { avoiding boundaries }\end{array}$ & 20 (2 groups) & 10 & $\mathrm{Y}$ \\
\hline $\begin{array}{l}\text { Chua et } \\
\text { al.[75] }\end{array}$ & Coordination & $\begin{array}{l}\text { Maximum } \\
\text { vertical jump }\end{array}$ & $\begin{array}{l}\text { Height measured using } \\
\text { VERT (wearable } \\
\text { accelerometer) }\end{array}$ & 36 (2 groups) & 18 & $\mathrm{Y}$ \\
\hline $\begin{array}{l}\text { LoJacono et } \\
\text { al.[76] }\end{array}$ & Coordination & $\begin{array}{l}\text { Obstacle } \\
\text { crossing }\end{array}$ & $\begin{array}{l}\text { Real and virtual } \\
\text { environments }\end{array}$ & 40 (2 groups) & 20 & $\mathrm{Y}$ \\
\hline $\begin{array}{l}\text { Wulf et } \\
\text { al.[77] }\end{array}$ & Coordination & Throwing & $\begin{array}{l}\text { Lasso to a target } 10 \\
\text { feet away }\end{array}$ & $\begin{array}{l}\text { Exp1: } 32(2 \\
\text { groups) Exp2: } \\
42 \text { (3 groups) }\end{array}$ & 14.8 & $\mathrm{Y}$ \\
\hline $\begin{array}{l}\text { Krause et } \\
\text { al.[78] }\end{array}$ & Sequence & \begin{tabular}{|l}
$\begin{array}{l}\text { Elbow flexion- } \\
\text { extension }\end{array}$ \\
\end{tabular} & $\begin{array}{l}70,20,70 \text { degs in } \\
1200 \mathrm{~ms}\end{array}$ & 42 (2 groups) & 21 & $\mathrm{Y}$ \\
\hline $\begin{array}{l}\text { Sobierajewicz } \\
\text { et al.[79] }\end{array}$ & Sequence & Keypress & $\begin{array}{l}5 \text { keypresses - as fast } \\
\text { as possible but with a } \\
\text { pause }\end{array}$ & 24 (2 groups) & 12 & $\mathrm{Y}$ \\
\hline $\begin{array}{l}\text { Neville and } \\
\text { Trempe [80] }\end{array}$ & Sequence & Keypress & $\begin{array}{l}5 \text { keypresses - as fast } \\
\text { as possible without } \\
\text { pause in } 30 \mathrm{~s}\end{array}$ & 42 (3 groups) & 14 & $\mathrm{Y}$ \\
\hline $\begin{array}{l}\text { Yokoi et al } \\
{[81]}\end{array}$ & Sequence & Keypress & $\begin{array}{l}5 \text { keypresses - as fast } \\
\text { without pause for } \\
\text { fixed number of } \\
\text { sequences }\end{array}$ & 32 (4 groups) & 8 & $\mathrm{Y}$ \\
\hline $\begin{array}{l}\text { Karlinsky and } \\
\text { Hodges [82] }\end{array}$ & Sequence & Keypress & $\begin{array}{l}5 \text { keypresses with } \\
\text { specified movement } \\
\text { times and only one } \\
\text { finger }\end{array}$ & $\begin{array}{l}94 \text { (6 } \\
\text { subgroups) }\end{array}$ & 15.67 & $\mathrm{Y}$ \\
\hline $\begin{array}{l}\text { Ruffino et } \\
\text { al.[83] }\end{array}$ & Sequence & Peg placing & $\begin{array}{l}\text { Modified version of } \\
\text { the NHPT }\end{array}$ & 20 (2 groups) & 10 & $\mathrm{Y}$ \\
\hline $\begin{array}{l}\text { Barros et al. } \\
{[84]}\end{array}$ & Sequence & Reaching & $\begin{array}{l}3 \text { item sequence with } \\
\text { specified times (Exp1) }\end{array}$ & $\begin{array}{l}\text { Exp1: } 60 \text { (4 } \\
\text { groups); }\end{array}$ & 15 & $\mathrm{Y}$ \\
\hline
\end{tabular}




\begin{tabular}{|c|c|c|c|c|c|c|}
\hline & & & $\begin{array}{l}\text { or specified forces } \\
\text { (Exp2) }\end{array}$ & $\begin{array}{l}\text { Exp2: } 60 \text { (4 } \\
\text { groups) }\end{array}$ & & \\
\hline $\begin{array}{l}\text { Kaipa et } \\
\text { al.[85] }\end{array}$ & Sequence & Speech & $\begin{array}{l}\text { Non meaningful } \\
\text { phrase with time } \\
\text { constraints }\end{array}$ & 80 (4 groups) & 20 & $\mathrm{Y}$ \\
\hline $\begin{array}{l}\text { Levac et } \\
\text { al.[86] }\end{array}$ & Sequence & Stepping & 6 step sequences & 40 (2 groups) & 20 & $\mathrm{Y}$ \\
\hline $\begin{array}{l}\text { Haarman et } \\
\text { al.[87] }\end{array}$ & Sequence & Walking & $\begin{array}{l}7 \text { step sequence (6 step } \\
\text { lengths) with targets } \\
\text { projected on to } \\
\text { treadmill }\end{array}$ & 20 (2 groups) & 10 & $\mathrm{Y}$ \\
\hline $\begin{array}{l}\text { Dotov and } \\
\text { Froese [88] }\end{array}$ & Tracking & $\begin{array}{l}\text { Auditory- } \\
\text { motor } \\
\text { synchronizatio } \\
\text { n task }\end{array}$ & $\begin{array}{l}\text { Hand-held } \\
\text { accelerometer } \\
\text { movements created } \\
\text { sounds that had to be } \\
\text { matched to target } \\
\text { sound }\end{array}$ & 48 (3 groups) & 16 & $\mathrm{Y}$ \\
\hline $\begin{array}{l}\text { Itaguchi and } \\
\text { Fukuzawa } \\
\text { [89] }\end{array}$ & Tracking & Drawing & $\begin{array}{l}\text { Draw a specific curved } \\
\text { shape in one stroke }\end{array}$ & 14 (2 groups) & 7 & $\mathrm{Y}$ \\
\hline $\begin{array}{l}\text { Fialho and } \\
\text { Tresilian [90] }\end{array}$ & Tracking & Interception & $\begin{array}{l}\text { Hitting a moving } \\
\text { target using a } \\
\text { manipulandum }\end{array}$ & 21 (3 groups) & 7 & $\mathrm{Y}$ \\
\hline $\begin{array}{l}\text { Yen et al. } \\
\text { [91] }\end{array}$ & Tracking & Reaching & $\begin{array}{l}\text { Move cursor in a } \\
\text { virtual maze using } \\
\text { isometric force }\end{array}$ & 20 (2 groups) & 10 & $\mathrm{Y}$ \\
\hline $\begin{array}{l}\text { Crespo et al. } \\
{[92]}\end{array}$ & Tracking & Tracking & $\begin{array}{l}\text { Tracking a virtual loop } \\
\text { through a continous or } \\
\text { discrete wire }\end{array}$ & 30 (3 groups) & 10 & $\mathrm{Y}$ \\
\hline $\begin{array}{l}\text { Boyer et } \\
\text { al.[93] }\end{array}$ & Tracking & Tracking & $\begin{array}{l}\text { Tracking randomly } \\
\text { moving target with } \\
\text { sonification of errors }\end{array}$ & $\begin{array}{l}\text { Exp 2: } 36 \\
\text { participants (3 } \\
\text { groups); Exp } \\
3: 36 \\
\text { participants (3 } \\
\text { groups); } 12 \\
\text { participants (1 } \\
\text { control group) }\end{array}$ & 12 & $\mathrm{Y}$ \\
\hline $\begin{array}{l}\text { Kaipa and } \\
\text { Kaipa [94] }\end{array}$ & Tracking & Tracking & $\begin{array}{l}\text { Used EMG from } \\
\text { mouth to track ramp of } \\
\text { upto } 40 \% \text { MVC }\end{array}$ & 45 (3 groups) & 15 & $\mathrm{Y}$ \\
\hline $\begin{array}{l}\text { Mansfield et } \\
\text { al.[95] }\end{array}$ & Variability & Balance & $\begin{array}{l}\text { Oscillating platforms } \\
\text { with varying } \\
\text { frequencies }\end{array}$ & $\begin{array}{l}48 \text { ( } 3 \text { groups); } \\
15 / 15 / 18\end{array}$ & 16 & $\mathrm{Y}$ \\
\hline $\begin{array}{l}\text { Ong and } \\
\text { Hodges [96] }\end{array}$ & Variability & Balance & Stand on Stabilometer & $\begin{array}{l}\text { Exp1: } 48 \text { (4 } \\
\text { groups); } \\
\text { Exp2: } 40 \text { (4 } \\
\text { groups) }\end{array}$ & 11 & $\mathrm{Y}$ \\
\hline $\begin{array}{l}\text { Meira and } \\
\text { Fairbrother } \\
\text { [97] }\end{array}$ & Variability & Balance & Stand on Stabilometer & $\begin{array}{l}\text { Exp1: } 56 \text { (4 } \\
\text { groups); } \\
\text { Exp2: } 48 \text { (4 } \\
\text { groups) }\end{array}$ & 13 & $\mathrm{~N}$ \\
\hline $\begin{array}{l}\text { Frank et } \\
\text { al.[98] }\end{array}$ & Variability & Golf putting & $\begin{array}{l}3 \mathrm{~m} \text { putt to hole on } \\
\text { artificial green }\end{array}$ & 24 (2 groups) & 12 & $\mathrm{Y}$ \\
\hline
\end{tabular}




\begin{tabular}{|l|l|l|l|l|l|l|}
\hline $\begin{array}{l}\text { Raisbeck and } \\
\text { Diekfuss[99] }\end{array}$ & Variability & Pistol shooting & $\begin{array}{l}15 \text { feet from target; } \\
2.5 / 5 \mathrm{~cm} \text { target }\end{array}$ & 68 (4 groups) & 17 & $\mathrm{Y}$ \\
\hline $\begin{array}{l}\text { Pacheco and } \\
\text { Newell [100] }\end{array}$ & Variability & Throwing & $\begin{array}{l}\text { Ball toss to hexagonal } \\
\text { and square targets } \\
\text { placed 2.05 m away }\end{array}$ & 24 (3 groups) & 8 & $\mathrm{Y}$ \\
\hline $\begin{array}{l}\text { Ginneken et } \\
\text { al. [101] }\end{array}$ & Variability & Throwing & $\begin{array}{l}\text { Ball toss to target 4m } \\
\text { away }\end{array}$ & 40 (2 groups) & 20 & $\mathrm{Y}$ \\
\hline $\begin{array}{l}\text { Grand et al. } \\
{[102]}\end{array}$ & Variability & Throwing & $\begin{array}{l}\text { Beanbag toss over a } \\
\text { board to target } 3 \mathrm{~m} \\
\text { away }\end{array}$ & 70 (2 groups) & 35 & $\mathrm{Y}$ \\
\hline
\end{tabular}


Table 3. Review of selected motor learning studies using golf putting as a task in 2013-2018

\begin{tabular}{|c|c|c|c|c|c|}
\hline Authors & $\begin{array}{l}\text { Putting } \\
\text { Distance }\end{array}$ & $\begin{array}{l}\text { Target } \\
\text { Type }\end{array}$ & $\begin{array}{l}\text { Target } \\
\text { Size }\end{array}$ & Description of Surface & Performance measure(s) \\
\hline $\begin{array}{l}\text { Chauvel et } \\
\text { al. [103] }\end{array}$ & $\begin{array}{l}0.25,0.5 \\
0.75,1 \\
1.25,1.5 \\
1.75,2 \\
2.25\end{array}$ & Hole & $\begin{array}{l}11.4 \mathrm{~cm} \\
\text { dia }\end{array}$ & $\begin{array}{l}\text { Artificial turf indoor green } \\
2 \mathrm{~m} \text { x. } 2.7 \mathrm{~m}\end{array}$ & Number of successful putts \\
\hline $\begin{array}{l}\text { Daou et al. } \\
{[104]}\end{array}$ & $1.2 \mathrm{~m}$ & Point & $\begin{array}{l}\text { target } \\
\text { cross } \\
\text { made up } \\
\text { of two } \\
10.8 \mathrm{~cm} \\
\text { pieces of } \\
\text { tape }\end{array}$ & Artificial grass surface & Radial error, bivariate error \\
\hline $\begin{array}{l}\text { Fazeli et al. } \\
{[105]}\end{array}$ & $\begin{array}{l}1.22 \\
2.44,3.66 \\
\mathrm{~m}\end{array}$ & Circle & $4 \mathrm{~cm} \mathrm{dia}$ & $\begin{array}{l}\text { Synthetic } 9 \mathrm{~m} \mathrm{x} 4 \mathrm{~m} \\
\text { putting green (STI Pro } \\
\text { Putt) }\end{array}$ & $\begin{array}{l}\text { Radial error measured from } \\
\text { edge of target }\end{array}$ \\
\hline $\begin{array}{l}\text { Palmer et al. } \\
{[106]}\end{array}$ & $1.5 \mathrm{~m}$ & Square & $\begin{array}{l}2 \times 2 \mathrm{~cm} \\
\text { square }\end{array}$ & $\begin{array}{l}4 \mathrm{~m} \times 0.55 \mathrm{~m} \text { level } \\
\text { artificial-turf indoor green }\end{array}$ & $\begin{array}{l}\text { Distance between center of } \\
\text { target and edge of ball; } \\
\text { distance counted as } 100 \mathrm{~cm} \\
\text { if rear border of green was } \\
\text { contacted }\end{array}$ \\
\hline $\begin{array}{l}\text { Zhu et al. } \\
\text { [107] }\end{array}$ & $1.9 \mathrm{~m}$ & Hole & $12 \mathrm{~cm} \mathrm{dia}$ & $\begin{array}{l}\text { Artificial grass putting } \\
\text { surface }\end{array}$ & Number of successful putts \\
\hline $\begin{array}{l}\text { Chauvel et } \\
\text { al. [108] }\end{array}$ & $2 \mathrm{~m}$ & Circle & $\begin{array}{l}10.4 \mathrm{~cm} \\
\mathrm{dia}\end{array}$ & $\begin{array}{l}4 \mathrm{~m} \times 0.55 \mathrm{~m} \text { level } \\
\text { artificial-turf indoor green }\end{array}$ & $\begin{array}{l}\text { Distance between center of } \\
\text { target and edge of ball; } \\
\text { distance counted as } 100 \mathrm{~cm} \\
\text { if rear border of green was } \\
\text { contacted }\end{array}$ \\
\hline $\begin{array}{l}\text { Ziv and } \\
\text { Lidor [109] }\end{array}$ & $2 \mathrm{~m}$ & Circle & $\begin{array}{l}10.8 \mathrm{~cm} \\
\text { dia }\end{array}$ & $1 \mathrm{~m} \times 4 \mathrm{~m}$ artificial grass & $\begin{array}{l}\text { Absolute error, variable } \\
\text { error }\end{array}$ \\
\hline $\begin{array}{l}\text { Abbas and } \\
\text { North }[110]\end{array}$ & $\begin{array}{l}2,5 \mathrm{~m} \\
\text { target } \\
\text { behind } \\
\text { opaque } \\
\text { curtain }\end{array}$ & Hole & $\begin{array}{l}10.61 \mathrm{~cm} \\
\text { dia }\end{array}$ & Flat carpeted surface & Radial error \\
\hline $\begin{array}{l}\text { Land et al. } \\
{[111]}\end{array}$ & $\begin{array}{l}2.0,2.75 \\
3.5,4.25 \\
5.0 \mathrm{~m}\end{array}$ & Circle & $\begin{array}{l}10.8 \mathrm{~cm} \\
\text { dia }\end{array}$ & $\begin{array}{l}4 \mathrm{~m} \times 9 \mathrm{~m} \text { artificial indoor } \\
\text { putting green }\end{array}$ & $\begin{array}{l}\text { Radial error, Bivariate radial } \\
\text { error }\end{array}$ \\
\hline $\begin{array}{l}\text { Nunes et al. } \\
{[112]}\end{array}$ & $\begin{array}{l}2.2,2.4 \\
3.2 \mathrm{~m}\end{array}$ & Hole & N/A & $\begin{array}{l}1.5 \mathrm{~m} \times 4 \mathrm{~m} \text { artificial } \\
\text { grass }\end{array}$ & Point system \\
\hline $\begin{array}{l}\text { Lawrence et } \\
\text { al. [113] }\end{array}$ & $2.25 \mathrm{~m}$ & Hole & $10 \mathrm{~cm}$ dia & $\begin{array}{l}\text { Astroturf surface, } 90-\mathrm{cm} \\
\text { incline slope of } 22 \\
\text { degrees that started } 72 \mathrm{~cm} \\
\text { from the start position }\end{array}$ & $\begin{array}{l}\text { Number of successful putts, } \\
\text { radial error }\end{array}$ \\
\hline $\begin{array}{l}\text { Ring et al. } \\
{[114]}\end{array}$ & $2.4 \mathrm{~m}$ & Hole & $\begin{array}{l}10.8 \mathrm{~cm} \\
\text { dia }\end{array}$ & $\begin{array}{l}\text { Flat artificial putting } \\
\text { surface (Turftiles) with } \\
\text { stimpmeter reading of } \\
3.05 \mathrm{~m}\end{array}$ & $\begin{array}{l}\text { Number of putts, radial } \\
\text { error; zero radial error if putt } \\
\text { was holed }\end{array}$ \\
\hline $\begin{array}{l}\text { Daou et al. } \\
{[115]}\end{array}$ & $3 \mathrm{~m}$ & Point & $\begin{array}{l}\text { target } \\
\text { cross } \\
\text { made up }\end{array}$ & Artificial grass surface & $\begin{array}{l}\text { Radial error, bivariate } \\
\text { variable error }\end{array}$ \\
\hline
\end{tabular}




\begin{tabular}{|c|c|c|c|c|c|}
\hline & & & $\begin{array}{l}\text { of two } \\
10.8 \mathrm{~cm} \\
\text { pieces of } \\
\text { tape }\end{array}$ & & \\
\hline $\begin{array}{l}\text { Frank et al. } \\
{[116]}\end{array}$ & $3 \mathrm{~m}$ & Circle & $\begin{array}{l}10.8 \mathrm{~cm} \\
\text { dia }\end{array}$ & $\begin{array}{l}4 \mathrm{~m} \times 7 \mathrm{~m} \text { artificial indoor } \\
\text { putting green }\end{array}$ & $\begin{array}{l}\text { Radial error, bivariate } \\
\text { variable error }\end{array}$ \\
\hline $\begin{array}{l}\text { Frank et } \\
\text { al.[117] }\end{array}$ & $3 \mathrm{~m}$ & Circle & $\begin{array}{l}10.8 \mathrm{~cm} \\
\text { dia }\end{array}$ & $\begin{array}{l}\text { Artificial indoor putting } \\
\text { green }\end{array}$ & $\begin{array}{l}\text { Radial error, bias, bivariate } \\
\text { variable error }\end{array}$ \\
\hline $\begin{array}{l}\text { Frank et } \\
\text { al.[118] }\end{array}$ & $3 \mathrm{~m}$ & Circle & $\begin{array}{l}10.8 \mathrm{~cm} \\
\text { dia }\end{array}$ & $\begin{array}{l}4 \mathrm{~m} \times 9 \mathrm{~m} \text { artificial indoor } \\
\text { putting green }\end{array}$ & $\begin{array}{l}\text { Radial error, bivariate } \\
\text { variable error }\end{array}$ \\
\hline $\begin{array}{l}\text { Kim et al. } \\
\text { [119] }\end{array}$ & $3 \mathrm{~m}$ & Circle & $\begin{array}{l}10.8 \mathrm{~cm} \\
\text { dia }\end{array}$ & $\begin{array}{l}4 \mathrm{~m} \times 9 \mathrm{~m} \text { synthetic } \\
\text { putting green }\end{array}$ & Radial error \\
\hline $\begin{array}{l}\text { Vine et al. } \\
{[120]}\end{array}$ & $3.05 \mathrm{~m}$ & Hole & $\begin{array}{l}10.8 \mathrm{~cm} \\
\text { dia }\end{array}$ & $\begin{array}{l}6 \times 2.5 \mathrm{~m} \text { artificial putting } \\
\text { green, stimpmeter reading } \\
3.28 \mathrm{~m}\end{array}$ & $\begin{array}{l}\text { Radial error; zero if putt was } \\
\text { holed }\end{array}$ \\
\hline $\begin{array}{l}\text { Krause et al. } \\
{[121]}\end{array}$ & $\begin{array}{l}3.3 \mathrm{~m} ; \\
\text { putt from } \\
\text { behind a } \\
\text { curtain }\end{array}$ & Point & N/A & $\begin{array}{l}\text { Carpet with comparable } \\
\text { conditions to a green }\end{array}$ & $\begin{array}{l}\text { Absolute error in distance } \\
\text { and angle }\end{array}$ \\
\hline $\begin{array}{l}\text { Kearney } \\
{[122]}\end{array}$ & $4 \mathrm{~m}$ & Circle & $10 \mathrm{~cm}$ dia & Indoor putting surface & Points system \\
\hline $\begin{array}{l}\text { Lewthwaite } \\
\text { et al. [123] }\end{array}$ & $4 \mathrm{~m}$ & Circle & $20 \mathrm{~cm} \mathrm{dia}$ & Floor & Points system \\
\hline $\begin{array}{l}\text { Munzert et } \\
\text { al. [124] }\end{array}$ & $4.50 \mathrm{~m}$ & Point & N/A & Indoor green & Absolute error \\
\hline
\end{tabular}




\section{References}

1. Mischel, W. (2008). The Toothbrush Problem. APS Obs. 21. Available at: https://www.psychologicalscience.org/observer/the-toothbrush-problem [Accessed April 4, 2019].

2. Bahrick, H.P., Fitts, P.M., and Briggs, G.E. (1957). Learning curves; facts or artifacts? Psychol. Bull. 54, 255-268.

3. Zwaan, R.A., Etz, A., Lucas, R.E., and Donnellan, M.B. (2018). Making replication mainstream. Behav. Brain Sci. 41. Available at:

https://www.cambridge.org/core/journals/behavioral-and-brain-sciences/article/makingreplication-mainstream/2E3D8805BF34927A76B963C7BBE36AC7 [Accessed August 29, 2019].

4. Camerer, C.F., Dreber, A., Holzmeister, F., Ho, T.-H., Huber, J., Johannesson, M., Kirchler, M., Nave, G., Nosek, B.A., Pfeiffer, T., et al. (2018). Evaluating the replicability of social science experiments in Nature and Science between 2010 and 2015. Nat. Hum. Behav. 2, 637.

5. Open Science Collaboration (2015). Estimating the reproducibility of psychological science. Science 349, aac4716.

6. Chambers, C.D. (2017). The Seven Deadly Sins of Psychology (Princeton, NJ: Princeton University Press).

7. Pashler, H., and Harris, C.R. (2012). Is the Replicability Crisis Overblown? Three Arguments Examined. Perspect. Psychol. Sci. 7, 531-536.

8. Newell, K.M. (1986). Constraints on the development of coordination. In Motor development in children: Aspects of coordination and control, M. G. Wade and H. T. A. Whiting, eds. (Nijhoff).

9. Newell, K.M. (1989). On task and theory specificity. J. Mot. Behav. 21, 92-96.

10. Lee, T.D., and Genovese, E.D. (1989). Distribution of Practice in Motor Skill Acquisition: Different Effects for Discrete and Continuous Tasks. Res. Q. Exerc. Sport $60,59-65$.

11. Wulf, G., and Shea, C.H. (2002). Principles derived from the study of simple skills do not generalize to complex skill learning. Psychon Bull Rev 9, 185-211.

12. Doyon, J., Korman, M., Morin, A., Dostie, V., Tahar, A.H., Benali, H., Karni, A., Ungerleider, L.G., and Carrier, J. (2009). Contribution of night and day sleep vs. simple passage of time to the consolidation of motor sequence and visuomotor adaptation learning. Exp. Brain Res. 195, 15-26.

13. Hasson, C.J., Zhang, Z., Abe, M.O., and Sternad, D. (2016). Neuromotor Noise Is Malleable by Amplifying Perceived Errors. PLoS Comput. Biol. 12, e1005044.

14. Kerr, R., and Booth, B. (1978). Specific and varied practice of motor skill. Percept. Mot. Skills 46, 395-401. 
15. Cardis, M., Casadio, M., and Ranganathan, R. (2018). High variability impairs motor learning regardless of whether it affects task performance. J. Neurophysiol. 119, 39-48.

16. Guadagnoli, M.A., and Lee, T.D. (2004). Challenge Point: A Framework for Conceptualizing the Effects of Various Practice Conditions in Motor Learning. J. Mot. Behav. 36, 212-224.

17. Button, K.S., Ioannidis, J.P.A., Mokrysz, C., Nosek, B.A., Flint, J., Robinson, E.S.J., and Munafò, M.R. (2013). Power failure: why small sample size undermines the reliability of neuroscience. Nat. Rev. Neurosci. 14, 365-376.

18. Lohse, K., Buchanan, T., and Miller, M. (2016). Underpowered and overworked: Problems with data analysis in motor learning studies. J. Mot. Learn. Dev. 4, 37-58.

19. Lakens, D., Scheel, A.M., and Isager, P.M. (2018). Equivalence Testing for Psychological Research: A Tutorial. Adv. Methods Pract. Psychol. Sci. 1, 259-269.

20. Albers, C., and Lakens, D. (2018). When power analyses based on pilot data are biased: Inaccurate effect size estimators and follow-up bias. J. Exp. Soc. Psychol. 74, 187-195.

21. Lo, A.C., Guarino, P.D., Richards, L.G., Haselkorn, J.K., Wittenberg, G.F., Federman, D.G., Ringer, R.J., Wagner, T.H., Krebs, H.I., Volpe, B.T., et al. (2010). Robot-assisted therapy for long-term upper-limb impairment after stroke. N Engl J Med 362, 1772-83.

22. Baguley, T. (2009). Standardized or simple effect size: what should be reported? Br. J. Psychol. Lond. Engl. 1953 100, 603-617.

23. Pinder, R.A., Davids, K., Renshaw, I., and Araújo, D. (2011). Representative Learning Design and Functionality of Research and Practice in Sport. J. Sport Exerc. Psychol. 33, $146-155$.

24. Krishnan, C., Washabaugh, E.P., and Seetharaman, Y. (2015). A low cost real-time motion tracking approach using webcam technology. J. Biomech. 48, 544-548.

25. Mathis, A., Mamidanna, P., Cury, K.M., Abe, T., Murthy, V.N., Mathis, M.W., and Bethge, M. (2018). DeepLabCut: markerless pose estimation of user-defined body parts with deep learning. Nat. Neurosci. 21, 1281-1289.

26. Gorgolewski, K.J., and Poldrack, R.A. (2016). A Practical Guide for Improving Transparency and Reproducibility in Neuroimaging Research. PLOS Biol. 14, e1002506.

27. Klein, O., Hardwicke, T.E., Aust, F., Breuer, J., Danielsson, H., Mohr, A.H., Ijzerman, H., Nilsonne, G., Vanpaemel, W., and Frank, M.C. (2018). A Practical Guide for Transparency in Psychological Science. Collabra Psychol. 4, 20.

28. Gilmore, R.O., and Adolph, K.E. (2017). Video can make behavioural science more reproducible. Nat. Hum. Behav. 1, 0128.

29. Moshontz, H., Campbell, L., Ebersole, C.R., IJzerman, H., Urry, H.L., Forscher, P.S., Grahe, J.E., McCarthy, R.J., Musser, E.D., Antfolk, J., et al. (2018). The Psychological 
Science Accelerator: Advancing Psychology Through a Distributed Collaborative Network. Adv. Methods Pract. Psychol. Sci. 1, 501-515.

30. Simmons, J.P., Nelson, L.D., and Simonsohn, U. (2011). False-positive psychology: undisclosed flexibility in data collection and analysis allows presenting anything as significant. Psychol Sci 22, 1359-66.

31. Swinnen, S.P. (1996). Information feedback for motor skill learning: A review. Adv. Mot. Learn. Control, 37-66.

32. Russell, D.M., and Newell, K.M. (2007). On No-KR tests in motor learning, retention and transfer. Hum Mov Sci 26, 155-73.

33. Walker, B., and Kording, K. (2013). The Database for Reaching Experiments and Models. PLOS ONE 8, e78747.

34. He, K., Liang, Y., Abdollahi, F., Fisher Bittmann, M., Kording, K., and Wei, K. (2016). The statistical determinants of the speed of motor learning. PLoS Comput Biol 12, e1005023.

35. Caldwell, A., Vigotsky, A.D., Nuckols, G., Boardley, I., Schmidt, J., Tenan, M., Skarabot, J., Radel, R., Naughton, M., Schoenfeld, B.J., et al. (2019). Moving Sport and Exercise Science Forward: A Call for the Adoption of More Transparent Research Practices (SportRxiv) Available at: https://osf.io/fxe7a [Accessed July 16, 2019].

36. Chambers, C.D. (2013). Registered reports: a new publishing initiative at Cortex. Cortex J. Devoted Study Nerv. Syst. Behav. 49, 609-610.

37. Yartsev, M.M. (2017). The emperor's new wardrobe: Rebalancing diversity of animal models in neuroscience research. Science 358, 466-469.

38. Adams, J.A. (1971). A closed-loop theory of motor learning. J. Mot. Behav. 3, 111-150.

39. Couth, S., Gowen, E., and Poliakoff, E. (2018). How does ageing affect grasp adaptation to a visual-haptic size conflict? Exp. Brain Res. 236, 2173-2184.

40. McGregor, H.R., Cashaback, J.G.A., and Gribble, P.L. (2018). Somatosensory perceptual training enhances motor learning by observing. J. Neurophysiol. 120, 30173025 .

41. McGregor, H.R., and Gribble, P.L. (2017). Functional connectivity between somatosensory and motor brain areas predicts individual differences in motor learning by observing. J. Neurophysiol. 118, 1235-1243.

42. McKenna, E., Bray, L.C.J., Zhou, W., and Joiner, W.M. (2017). The absence or temporal offset of visual feedback does not influence adaptation to novel movement dynamics. J. Neurophysiol. 118, 2483-2498.

43. Milner, T.E., Firouzimehr, Z., Babadi, S., and Ostry, D.J. (2018). Different adaptation rates to abrupt and gradual changes in environmental dynamics. Exp. Brain Res. 236, 2923-2933. 
44. Melendez-Calderon, A., Tan, M., Bittmann, M.F., Burdet, E., and Patton, J.L. (2017). Transfer of dynamic motor skills acquired during isometric training to free motion. J. Neurophysiol. 118, 219-233.

45. Kumar, N., Kumar, A., Sonane, B., and Mutha, P.K. (2018). Interference between competing motor memories developed through learning with different limbs. J. Neurophysiol. 120, 1061-1073.

46. Schmitz, G., and Bock, O.L. (2017). Properties of intermodal transfer after dual visuoand auditory-motor adaptation. Hum. Mov. Sci. 55, 108-120.

47. Aiken, C.A., Pan, Z., and Van Gemmert, A.W.A. (2017). The effects of a two-step transfer on a visuomotor adaptation task. Exp. Brain Res. 235, 3459-3467.

48. Holland, P., Codol, O., and Galea, J.M. (2018). Contribution of explicit processes to reinforcement-based motor learning. J. Neurophysiol. 119, 2241-2255.

49. Canaveral, C.A., Danion, F., Berrigan, F., and Bernier, P.-M. (2017). Variance in exposed perturbations impairs retention of visuomotor adaptation. J. Neurophysiol. 118, $2745-2754$.

50. Jiang, W., Yuan, X., Yin, C., and Wei, K. (2018). Visuomotor learning is dependent on direction-specific error saliency. J. Neurophysiol. 120, 162-170.

51. Jalali, R., Miall, R.C., and Galea, J.M. (2017). No consistent effect of cerebellar transcranial direct current stimulation on visuomotor adaptation. J. Neurophysiol. 118, $655-665$.

52. Leow, L.-A., Gunn, R., Marinovic, W., and Carroll, T.J. (2017). Estimating the implicit component of visuomotor rotation learning by constraining movement preparation time. J. Neurophysiol. 118, 666-676.

53. Song, Y., and Smiley-Oyen, A.L. (2017). Probability differently modulating the effects of reward and punishment on visuomotor adaptation. Exp. Brain Res. 235, 3605-3618.

54. Reilly, K.J., and Pettibone, C. (2017). Vowel generalization and its relation to adaptation during perturbations of auditory feedback. J. Neurophysiol. 118, 2925-2934.

55. Seidler, R.D., Gluskin, B.S., and Greeley, B. (2016). Right prefrontal cortex transcranial direct current stimulation enhances multi-day savings in sensorimotor adaptation. J. Neurophysiol. 117, 429-435.

56. Cattan, E., Perrier, P., Bérard, F., Gerber, S., and Rochet-Capellan, A. (2018). Adaptation to visual feedback delays on touchscreens with hand vision. Exp. Brain Res. 236, 3191-3201.

57. French, M.A., Morton, S.M., Charalambous, C.C., and Reisman, D.S. (2018). A locomotor learning paradigm using distorted visual feedback elicits strategic learning. J. Neurophysiol. 120, 1923-1931. 
58. Maeda, R.S., McGee, S.E., and Marigold, D.S. (2016). Consolidation of visuomotor adaptation memory with consistent and noisy environments. J. Neurophysiol. 117, 316326.

59. Hinkel-Lipsker, J.W., and Hahn, M.E. (2017). The effects of variable practice on locomotor adaptation to a novel asymmetric gait. Exp. Brain Res. 235, 2829-2841.

60. Hinkel-Lipsker, J.W., and Hahn, M.E. (2018). Coordinative structuring of gait kinematics during adaptation to variable and asymmetric split-belt treadmill walking A principal component analysis approach. Hum. Mov. Sci. 59, 178-192.

61. Day, K.A., Leech, K.A., Roemmich, R.T., and Bastian, A.J. (2018). Accelerating locomotor savings in learning: compressing four training days to one. J. Neurophysiol. $119,2100-2113$.

62. Kim, J.H., Han, J.K., and Han, D.H. (2018). Training effects of Interactive Metronome ${ }^{\circledR}$ on golf performance and brain activity in professional woman golf players. Hum. Mov. Sci. 61, 63-71.

63. Navarro, M., van der Kamp, J., Schor, P., and Savelsbergh, G.J.P. (2018). Implicit learning increases shot accuracy of football players when making strategic decisions during penalty kicking. Hum. Mov. Sci. 61, 72-80.

64. Chien, K.-P., and Chen, S. (2018). The Influence of Guided Error-Based Learning on Motor Skills Self-Efficacy and Achievement. J. Mot. Behav. 50, 275-284.

65. Krajenbrink, H., van Abswoude, F., Vermeulen, S., van Cappellen, S., and Steenbergen, B. (2018). Motor learning and movement automatization in typically developing children: The role of instructions with an external or internal focus of attention. Hum. Mov. Sci. 60, 183-190.

66. Hebert, E. (2018). The Effects of Observing a Learning Model (or Two) on Motor Skill Acquisition. J. Mot. Learn. Dev. 6, 4-17.

67. Lin, T.-H., Denomme, A., and Ranganathan, R. (2018). Learning alternative movement coordination patterns using reinforcement feedback. Exp. Brain Res. Available at: https://doi.org/10.1007/s00221-018-5227-1.

68. Panzer, S., Kennedy, D., Wang, C., and Shea, C.H. (2018). The simplest acquisition protocol is sometimes the best protocol: performing and learning a 1:2 bimanual coordination task. Exp. Brain Res. 236, 539-550.

69. Bingham, G.P., Snapp-Childs, W., and Zhu, Q. (2018). Information about relative phase in bimanual coordination is modality specific (not amodal), but kinesthesis and vision can teach one another. Hum. Mov. Sci. 60, 98-106.

70. Dyer, J.F., Stapleton, P., and Rodger, M.W.M. (2017). Advantages of melodic over rhythmic movement sonification in bimanual motor skill learning. Exp. Brain Res. 235, 3129-3140.

71. Cardis, M., Casadio, M., and Ranganathan, R. (2017). High variability impairs motor learning regardless of whether it affects task performance. J. Neurophysiol. 119, 39-48. 
72. Thorp, E.B., Kording, K.P., and Mussa-Ivaldi, F.A. (2016). Using noise to shape motor learning. J. Neurophysiol. 117, 728-737.

73. Kimura, T., Kaneko, F., Nagahata, K., Shibata, E., and Aoki, N. (2017). Working Memory Training Improves Dual-Task Performance on Motor Tasks. J. Mot. Behav. 49, 388-397.

74. Shuggi, I.M., Shewokis, P.A., Herrmann, J.W., and Gentili, R.J. (2018). Changes in motor performance and mental workload during practice of reaching movements: a team dynamics perspective. Exp. Brain Res. 236, 433-451.

75. Chua, L.-K., Wulf, G., and Lewthwaite, R. (2018). Onward and upward: Optimizing motor performance. Hum. Mov. Sci. 60, 107-114.

76. LoJacono, C.T., MacPherson, R.P., Kuznetsov, N.A., Raisbeck, L.D., Ross, S.E., and Rhea, C.K. (2018). Obstacle Crossing in a Virtual Environment Transfers to a Real Environment. J. Mot. Learn. Dev. 6, 234-249.

77. Wulf, G., Iwatsuki, T., Machin, B., Kellogg, J., Copeland, C., and Lewthwaite, R. (2018). Lassoing Skill Through Learner Choice. J. Mot. Behav. 50, 285-292.

78. Krause, D., Agethen, M., and Zobe, C. (2018). Error Feedback Frequency Affects Automaticity But Not Accuracy and Consistency After Extensive Motor Skill Practice. J. Mot. Behav. 50, 144-154.

79. Sobierajewicz, J., Przekoracka-Krawczyk, A., Jaśkowski, W., and van der Lubbe, R.H.J. (2017). How effector-specific is the effect of sequence learning by motor execution and motor imagery? Exp. Brain Res. 235, 3757-3769.

80. Neville, K.-M., and Trempe, M. (2017). Serial practice impairs motor skill consolidation. Exp. Brain Res. 235, 2601-2613.

81. Yokoi, A., Bai, W., and Diedrichsen, J. (2016). Restricted transfer of learning between unimanual and bimanual finger sequences. J. Neurophysiol. 117, 1043-1051.

82. Karlinsky, A., and Hodges, N.J. (2018). Dyad Practice Impacts Self-Directed Practice Behaviors and Motor Learning Outcomes in a Contextual Interference Paradigm. J. Mot. Behav. 50, 579-589.

83. Ruffino, C., Papaxanthis, C., and Lebon, F. (2017). The influence of imagery capacity in motor performance improvement. Exp. Brain Res. 235, 3049-3057.

84. Barros, J.A. de C., Tani, G., and Corrêa, U.C. (2017). Effects of practice schedule and task specificity on the adaptive process of motor learning. Hum. Mov. Sci. 55, 196-210.

85. Kaipa, R., Robb, M., and Jones, R. (2017). The Effectiveness of Constant, Variable, Random, and Blocked Practice in Speech-Motor Learning. J. Mot. Learn. Dev. 5, 103125.

86. Levac, D., Driscoll, K., Galvez, J., Mercado, K., and O’Neil, L. (2017). OPTIMAL practice conditions enhance the benefits of gradually increasing error opportunities on retention of a stepping sequence task. Hum. Mov. Sci. 56, 129-138. 
87. Haarman, J.A.M., Choi, J.T., Buurke, J.H., Rietman, J.S., and Reenalda, J. (2017). Performance of a visuomotor walking task in an augmented reality training setting. Hum. Mov. Sci. 56, 11-19.

88. Fialho, J.V.A.P., and Tresilian, J.R. (2017). Intercepting accelerated moving targets: effects of practice on movement performance. Exp. Brain Res. 235, 1257-1268.

89. Itaguchi, Y., and Fukuzawa, K. (2018). Influence of Speed and Accuracy Constraints on Motor Learning for a Trajectory-Based Movement. J. Mot. Behav. 50, 653-663.

90. Dotov, D., and Froese, T. (2018). Entraining chaotic dynamics: A novel movement sonification paradigm could promote generalization. Hum. Mov. Sci. 61, $27-41$.

91. Yen, S.-C., Olsavsky, L.C., Cloonan, C.M., Llanos, A.R., Dwyer, K.J., Nabian, M., and Farjadian, A.B. (2018). An examination of lower limb asymmetry in ankle isometric force control. Hum. Mov. Sci. 57, 40-49.

92. Marchal-Crespo, L., Rappo, N., and Riener, R. (2017). The effectiveness of robotic training depends on motor task characteristics. Exp. Brain Res. 235, 3799-3816.

93. Boyer, É.O., Bevilacqua, F., Susini, P., and Hanneton, S. (2017). Investigating three types of continuous auditory feedback in visuo-manual tracking. Exp. Brain Res. 235, 691-701.

94. Kaipa, R., and Kaipa, R.M. (2018). Role of Constant, Random and Blocked Practice in an Electromyography-Based Oral Motor Learning Task. J. Mot. Behav. 50, 599-613.

95. Mansfield, A., Aqui, A., Fraser, J.E., Rajachandrakumar, R., Lakhani, B., and Patterson, K.K. (2017). Can augmented feedback facilitate learning a reactive balance task among older adults? Exp. Brain Res. 235, 293-304.

96. Ong, N.T., and Hodges, N.J. (2018). Balancing Our Perceptions of the Efficacy of Success-Based Feedback Manipulations on Motor Learning. J. Mot. Behav. 50, 614630.

97. Meira, C.M., and Fairbrother, J.T. (2018). Ego-Oriented Learners Show Advantage in Retention and Transfer of Balancing Skill. J. Mot. Learn. Dev. 6, 209-219.

98. Frank, C., Kim, T., and Schack, T. (2018). Observational Practice Promotes ActionRelated Order Formation in Long-Term Memory: Investigating Action Observation and the Development of Cognitive Representation in Complex Motor Action. J. Mot. Learn. Dev. 6, 53-72.

99. Raisbeck, L.D., and Diekfuss, J.A. (2017). Verbal Cues and Attentional Focus: A Simulated Target-Shooting Experiment. J. Mot. Learn. Dev. 5, 148-159.

100. Pacheco, M.M., and Newell, K.M. (2018). Learning a specific, individual and generalizable coordination function: evaluating the variability of practice hypothesis in motor learning. Exp. Brain Res. 236, 3307-3318. 
101. Ginneken, W.F. van, Poolton, J.M., Capio, C.M., Kamp, J. van der, Choi, C.S.Y., and Masters, R.S.W. (2018). Conscious Control Is Associated With Freezing of Mechanical Degrees of Freedom During Motor Learning. J. Mot. Behav. 50, 436-456.

102. Grand, K.F., Daou, M., Lohse, K.R., and Miller, M.W. (2017). Investigating the Mechanisms Underlying the Effects of an Incidental Choice on Motor Learning. J. Mot. Learn. Dev. 5, 207-226.

103. Chauvel, G., Maquestiaux, F., Ruthruff, E., Didierjean, A., and Hartley, A.A. (2013). Novice motor performance: Better not to verbalize. Psychon. Bull. Rev. 20, 177-183.

104. Daou, M., Lohse, K.R., and Miller, M.W. (2016). Expecting to teach enhances motor learning and information processing during practice. Hum. Mov. Sci. 49, 336-345.

105. Fazeli, D., Taheri, H., and Saberi Kakhki, A. (2017). Random Versus Blocked Practice to Enhance Mental Representation in Golf Putting. Percept. Mot. Skills 124, 674-688.

106. Palmer, K., Chiviacowsky, S., and Wulf, G. (2016). Enhanced expectancies facilitate golf putting. Psychol. Sport Exerc. 22, 229-232.

107. Zhu, F.F., Yeung, A.Y., Poolton, J.M., Lee, T.M.C., Leung, G.K.K., and Masters, R.S.W. (2015). Cathodal Transcranial Direct Current Stimulation Over Left Dorsolateral Prefrontal Cortex Area Promotes Implicit Motor Learning in a Golf Putting Task. Brain Stimulat. 8, 784-786.

108. Chauvel, G., Wulf, G., and Maquestiaux, F. (2015). Visual illusions can facilitate sport skill learning. Psychon. Bull. Rev. 22, 717-721.

109. Ziv, G., and Lidor, R. (2015). Focusing attention instructions, accuracy, and quiet eye in a self-paced task - an exploratory study. Int. J. Sport Exerc. Psychol. 13, 104-120.

110. Abbas, Z.A., and North, J.S. (2018). Good-vs. poor-trial feedback in motor learning: The role of self-efficacy and intrinsic motivation across levels of task difficulty. Learn. Instr. 55, 105-112.

111. Land, W.M., Frank, C., and Schack, T. (2014). The influence of attentional focus on the development of skill representation in a complex action. Psychol. Sport Exerc. 15, 3038 .

112. Nunes, M.E. de S., Correa, U.C., Souza, M.G.T.X. de, Basso, L., Coelho, D.B., and Santos, S. (2019). No Improvement on the Learning of Golf Putting By Older Persons With Self-Controlled Knowledge of Performance. J. Aging Phys. Act. 27, 300-308.

113. Lawrence, G.P., Cassell, V.E., Beattie, S., Woodman, T., Khan, M.A., Hardy, L., and Gottwald, V.M. (2014). Practice with anxiety improves performance, but only when anxious: evidence for the specificity of practice hypothesis. Psychol. Res. 78, 634-650.

114. Ring, C., Cooke, A., Kavussanu, M., McIntyre, D., and Masters, R. (2015). Investigating the efficacy of neurofeedback training for expediting expertise and excellence in sport. Psychol. Sport Exerc. 16, 118-127. 
115. Daou, M., Hutchison, Z., Bacelar, M., Rhoads, J.A., Lohse, K.R., and Miller, M.W. (2019). Learning a skill with the expectation of teaching it impairs the skill's execution under psychological pressure. J. Exp. Psychol. Appl. 25, 219-229.

116. Frank, C., Land, W.M., and Schack, T. (2013). Mental representation and learning: The influence of practice on the development of mental representation structure in complex action. Psychol. Sport Exerc. 14, 353-361.

117. Frank, C., Land, W.M., Popp, C., and Schack, T. (2014). Mental representation and mental practice: experimental investigation on the functional links between motor memory and motor imagery. PloS One 9, e95175.

118. Frank, C., Land, W.M., and Schack, T. (2016). Perceptual-Cognitive Changes During Motor Learning: The Influence of Mental and Physical Practice on Mental Representation, Gaze Behavior, and Performance of a Complex Action. Front. Psychol. 6. Available at: https://www.frontiersin.org/articles/10.3389/fpsyg.2015.01981/full [Accessed August 27, 2019].

119. Kim, T., Frank, C., and Schack, T. (2017). A Systematic Investigation of the Effect of Action Observation Training and Motor Imagery Training on the Development of Mental Representation Structure and Skill Performance. Front. Hum. Neurosci. Available at: https://link-galegroupcom.proxy2.cl.msu.edu/apps/doc/A511188490/AONE?sid=lms [Accessed August 27, 2019].

120. Vine, S., Moore, L., Cooke, A., Ring, C., and Wilson, M. (2013). Quiet eye training: A means to implicit motor learning Quiet eye training: A means to implicit motor learning. Int. J. Sport Psychol. 44, 367.

121. Krause, D., Brüne, A., Fritz, S., Kramer, P., Meisterjahn, P., Schneider, M., and Sperber, A. (2014). Learning of a Golf Putting Task with Varying Contextual Interference Levels Induced by Feedback Schedule in Novices and Experts. Percept. Mot. Skills 118, 384-399.

122. Kearney, P.E. (2015). A distal focus of attention leads to superior performance on a golf putting task. Int. J. Sport Exerc. Psychol. 13, 371-381.

123. Lewthwaite, R., Chiviacowsky, S., Drews, R., and Wulf, G. (2015). Choose to move: The motivational impact of autonomy support on motor learning. Psychon. Bull. Rev. $22,1383-1388$.

124. Munzert, J., Maurer, H., and Reiser, M. (2014). Verbal-Motor Attention-Focusing Instructions Influence Kinematics and Performance on a Golf-Putting Task. J. Mot. Behav. 46, 309-318. 